\title{
Overadaptation to Climate Change? The Case of the 2013 Finnish Electricity Market Act
}

\author{
Väinö Nurmi ${ }^{1,2} \cdot$ Karoliina Pilli-Sihvola $^{1,2}$ (D) Hilppa Gregow ${ }^{1} \cdot$ Adriaan Perrels $^{1}$
}

Received: 12 June 2018 / Accepted: 27 December 2018 /Published online: 20 February 2019

(C) The Author(s) 2019

\begin{abstract}
In this paper, we put forward a definition of over-adaptation in disaster risk reduction (DRR) and climate change adaptation (CCA) projects. We detail an illustrative case in which the response to extreme weather risk while aligned with the goals of CCA, is implemented beyond the economically efficient scale. We undertake a cost-benefit analysis of the 2013 Finnish Electricity Market Act, enacted partially as a reaction to long, storm-induced electricity blackouts experienced after 2000. The Act imposes strict requirements on electricity distribution companies as regards the duration of blackouts. Meeting these requirements entails investments amounting to billions of euros. As a benefit, we quantify the avoided cost from the blackouts for households and producers. Our results, derived from Monte-Carlo simulations, show that for urban areas, the net expected value is positive. However, in rural areas less strict requirements could have been economically more efficient. Our results indicate that distributional impacts and correspondence between those who benefit and those who pay the costs should be taken into account in DRR and CCA policies that require large-scale investments. We also note that the population affected by a disaster may not accept DRR and CCA that are successful in terms of regulation and implementation. This applies when societal and individual preferences do not coincide.
\end{abstract}

Keywords Economic analysis · Electricity grid · Energy policy · Policy assessment · Public good provision $\cdot$ Climate change adaptation

Karoliina Pilli-Sihvola

karoliina.pilli-sihvola@fmi.fi

Väinö Nurmi

vaino.nurmi@fmi.fi

Finnish Meteorological Institute, P.O. Box 503, fi-00101 Helsinki, Finland

2 Faculty of Agriculture and Forestry, University of Helsinki, P.O. Box 27, 00014 Helsinki, Finland 


\section{Introduction}

\section{Economic Analysis of Disaster Risk Reduction and Climate Change Adaptation Measures}

Various measures have been implemented or proposed to reduce the impacts of extreme weather events on, and the increasing threat of climate change to, communities, the economy and societies, (e.g. Hallegatte 2009; Konrad and Thum 2014). The goal of such measures is to reduce the exposure and vulnerability of people and assets to natural hazards and climate change and thereby to mitigate their impacts (IPCC 2012). Both climate change adaptation (CCA) and disaster risk reduction (DRR) are cross-cutting policy fields, implying that the respective goals are seldom the only goals of a given sectorial policy or measure. For example, in the public sector, DRR and CCA goals are pursued by first integrating relevant DRR and CCA policy instruments into sectorial policies and then ensuring that the sectorial policy goals are harmonised with the goals of DRR and CCA. (COM 2013; Rivera et al. 2015; Pilli-Sihvola and Väätäinen-Chimpuku 2016).

From an economic perspective, there are several criteria for assessing DRR and CCA policy instruments. The Potential Pareto Improvement (PPI) criterion states that the aggregate level of benefits should exceed the costs (e.g. Freeman et al. 2014). A stricter criterion of Pareto optimality requires optimality in the sense that the aggregate benefits of the policy instrument are maximised by equating the marginal benefits to the marginal costs (e.g. Mendelsohn 2012). Whether these criteria are met can be determined by using cost-benefit analysis (CBA). CBA and cost-effectiveness analysis are traditional tools for determining the economic efficiency of public sector policies and projects (Boardman et al. 2006; Smith et al. 2017) and they have also been used extensively for analysing DRR and CCA measures (Shreve and Kelman 2014).

The aim of this paper is to analyse whether over-investment in DRR and CCA occurs, and how the public reacts to major infrastructure investments whose costs they must eventually bear. In the process, we clarify issues related to applying CBA in CCA- and DRR-related investments. We undertake an in medias res social CBA on the amended Finnish Electricity Market Act, passed in 2013 (588/2013). Among its other goals, the Act seeks to decrease the susceptibility of the electricity network to extreme weather and to make distribution companies adapt to changing weather patterns. This has required major investments in resilient electricity distribution networks. The measures required by the Act sparked an intense public debate, as they were followed by substantial increases in the distribution rates (in Finland, production and distribution are separated), and raised the question of whether the policy was an overreaction from an economic point of view. As a sizable investment in DRR and CCA with quantifiable benefits, costs and uncertainty, the project serves as a good case for using a CBA to evaluate DRR and CCA measures from an economic perspective.

Based on the analysis in Shreve and Kelman (2014), a considerable majority of the costbenefit analyses in the literature have concluded that investing in DRR and CCA measures is beneficial; that is, benefits exceed costs. However, this evidence alone does not warrant the conclusion that DRR and CCA investments are economically efficient and advisable. Indeed, the analysis in Shreve and Kelman (2014) indicates that ex-ante CBAs showing that benefits do not exceed costs are not reported in the literature: no investment was made and no study published. In other words, the CBAs reported suffer from publication bias in that only highly positive or highly negative results have been published (on publication bias, see Easterbrook et al. 1991; Møller and Jennions 2001; in the CBA literature, see Bell et al. 2006) and the hazards studied 
have been based on the ease of calculating the benefits (Shreve and Kelman 2014). The CCA options reported have been almost exclusively favourable ones, although occasional reports of maladaptation have appeared (Noble et al. 2014).

In section "Background to the Case Study", we present the political background of the case study. Second section goes on to provide an economic definition of the case where marginal costs exceed marginal benefits and defines this as over-adaptation. In third section we discuss cost-benefit analysis (CBA) as a method and the data for our case study. Fourth section describes the results and gives a short account of the public reaction to the Act and the public sector's response to this. In fifth section, we consider the limitations of the analysis and prospects for future research. Sixth section concludes with a discussion of the policy implications of the study.

\section{Background to the Case Study}

Finland is a highly developed northern European country where long-term policy and cultural development have averted disasters triggered by natural hazards, (see e.g. Pilli-Sihvola et al. 2017). The Finnish approach to security could be said to exhibit highly risk-aversive preferences (Saastamoinen and Kuosmanen 2016); indeed, they approach lexicographic preferences, with the security of the country and its citizens being the most preferred asset regardless of economic considerations. The major risks are extra-tropical cyclones, winter storms and major snow loads, which cause trees to fall on power lines, resulting in long blackouts. Accordingly, one of the goals of the revised 2013 Electricity Market Act was to reduce the impacts of extreme weather on Finnish electricity consumers with due consideration of the altered weather patterns that climate change will bring. Long blackouts such as those experienced in summer 2010 prompted a need to boost investments in the electricity distribution network, and imposing strict requirements on the permissible duration of the blackouts was considered an effective way to do so (Government Proposal HE 20/2013). The policy process to revise the legislation started quite a bit earlier, in 2001.

The first analyses on the need to reform the legislation were undertaken in 2001. These studies (see Appendix for the list of background studies done prior to the 2013 Act) concluded that the law had to be updated to meet the changing environmental and societal conditions and that it had to include measurable targets. As drafting began, various limits on the length of power outages were assessed. The technology was outdated, and major investments were needed to upgrade it to meet the standards for modern electricity and telecommunication infrastructure and societal structures. Moreover, changes in forest management had increased the exposure of the distribution network to storm and snow damage, and this vulnerability had to be reduced. Two storms in 2001, major thunderstorms in 2010 and heavy snow loads in 2011 (see Fig. 4) highlighted the need to overhaul the distribution network.

The requirements of the 2013 Electricity Market Act are an example of a policy instrument that could substantially reduce the impacts of weather extremes and climate change, for the investments it necessitates would eliminate most of the threat of trees damaging power lines. The Act imposes strict requirements on the duration of blackouts: in rural areas (excluding premises without permanent residents) they should not last no longer than $36 \mathrm{~h}$, and in urban areas no longer than $6 \mathrm{~h}$. The transition period for meeting the requirements extends until 2029, with mid-term goals to be reached by 2019 and 2023 (Electricity Market Act 2013). The upshot of these requirements is that electricity distribution companies have to improve the reliability of their networks, mainly by replacing traditional overhead lines with underground 
ones (Partanen et al. 2012; Saastamoinen and Kuosmanen 2016). The preliminary assessments undertaken prior to the Act indicate that underground cabling is the only way to ensure compliance with the requirements of the Act where the low- and medium-voltage networks are concerned (Partanen et al. 2012). High-voltage power lines in Finland are already weather resilient, as buffer zones are cleared around them.

The three main goals of the 2013 Act (588/2013) are reliability of electricity supply, affordable rates and reasonable service principles (s. 1). The Act contains explicit references to the capability required of the electricity transmission and distribution systems if they are to withstand normal, expected Finnish climate conditions. In this respect, the Act has integrated DRR and CCA needs quite well, and research findings (Gregow et al. 2011) on the changing risk to forests due to climate change were used when the Act was being drafted. The Act (s. 24) also states that transmission rates and conditions need to be equal and non-discriminatory for all consumers. However, the goal of affordable rates for commercial and residential users, justified in terms of strategic goals for economic and social development, partly conflicts with the aims of reliability and reasonable service principles. Compliance with the 2013 Act has required considerable investment on the part of the network companies. The sharp increase in the price of electricity distribution for consumers that followed its enactment led to a major public debate. This and ensuing parliamentary debates, in turn, resulted in the revision of the Act in 2017. The revised Act states that, in principle, price rises should be moderate but that extraordinary costs can justify stronger price increases. The permissible durations for blackouts were not altered. Despite the revision of the Act on 2017, on 28 May 2018, the Ministry of Economic Affairs and Employment, which drafted the Act, ordered an investigation into the price rises and their spatial distribution due to sharp price increases witnessed after the coming into force of the Act.

The ministry commissioned several assessments of the Act during the period 2001-2013. Some of these included economic analyses; for example, Partanen et al. (2006) concluded that a fully underground cable network would be economically feasible only if the avoided cost were 2.5 times higher than the amount estimated at the time of the analysis for a 40 -year investment schedule. If the investment had to be made in a shorter time period (for example, prior to 2030, the end of the transition period allowed by the Act), the avoided cost would have to be 5.5 times higher than the estimates at the time. Later, Partanen et al. (2012) concluded that a time limit of $24 \mathrm{~h}$ for blackouts in rural areas, the limit considered initially, would not be economically efficient, and that a 36-h time limit would be preferable. However, the report only compared these two options and their economic feasibility. The legislative proposal (Government Proposal HE 20/2013) included an analysis of the avoided-cost based disutility for the consumers, but did not reach the level of detail of a thorough CBA.

\section{Economic Definition of over-Adaptation to Climate Change}

Climate change adaptation is the process of adjustment to actual or expected climate and its effects. The IPCC defines adaptation as follows: "In human systems, adaptation seeks to moderate or avoid harm or exploit beneficial opportunities. In some natural systems, human intervention may facilitate adjustment to expected climate and its effects". (IPCC 2014). In economic terms, adaptation seeks to reduce the costs related to climate change and, if possible, to turn the negative impacts into positive ones (Tol 2005). CCA can take place at different scales in economics: the economic agents are households, firms and the public sector. This paper focuses on public CCA. Adaptation can also be further broken down into two types, 
anticipatory (planned) and reactive (IPCC 2012; Perrels et al. 2013). In the present case adaptation is cast as anticipatory action resulting in protective investments. However, as discussed in section 1.2, the 2013 Electricity Act (and its induced investments) and revision in 2017 are steps in a learning process, one involving anticipation as well as reaction.

Investments and implementation of CCA measures can lead to three types of sub-optimality: 1) under-adaptation, which implies a lack of adequate CCA in the face of changing climate (Hanemann 2000; Quentin Grafton 2010); 2) over-adaptation, which implies an overreaction to the problem (Hanemann 2000); and 3) maladaptation, which is any action that increases vulnerability to climate change, increases the risk of negative outcomes or diminishes welfare (Barnett and O'Neill 2010; IPCC 2014). Maladaptation has been widely discussed in the literature, and some real-world examples have been presented (Noble et al. 2014). Underadaptation, or inadequate adaptation, has been identified as a potential threat: the actions taken may not be enough to adapt (Quentin Grafton 2010) or, for instance, the private sector may not have adequate incentives to implement CCA measures (Eisenack 2014). However, the literature on over-adaptation is virtually lacking: the only examples of over-adaptation that we were able to find in the literature were the few in Shreve and Kelman (2014), where the benefit-cost ratio of CCA investments was below 1. Despite the clear economic implications of overadaptation, no exact definition of it has been provided to date.

Many CCA decisions concern public policies, public goods or goods with characteristics of such goods (non-rivalry and non-excludability); examples include early warning systems or flood control systems. Optimal CCA for a public good, in terms of partial equilibrium, (e.g. Mendelsohn 2012; OCED, 2018) is to maximise the social net benefits from the provision of the (CCA) good:

$$
\max \sum B_{i}(Q)-C(Q),
$$

where $B_{i}$ is the net present value of the stream of expected value from the public CCA effort such that $B_{i}=\int E V\left(b_{i, t}\right) e^{-r t}, b_{i, t}$ the benefit for individual $\mathrm{i}$ at time $\mathrm{t}$, and $\mathrm{Q}$ the quantity of the public good. By differentiating with respect to $\mathrm{Q}$, we get the first order condition for the optimal CCA decision, where $M$ refers to marginal changes:

$$
\sum M B_{i}(Q)=M C(Q)
$$

Thus, at the optimum, the aggregated marginal benefits should match the marginal cost of provision of the public good. Several remarks are in order regarding the optimality conditions. First, in theory, the differences in the social marginal utility of money should be accounted in the aggregation process, a procedure known as distributional weighting. (e.g. Boadway 2006; Johansson-Stenman 2005; Adler 2016; Nurmi and Ahtiainen 2018). Secondly, the quantity of public CCA policy, or Q, is an abstract measure reflecting the scale of the proposed action. In our case study, for example, the quantity of public policy refers to the extent to which the electric grid needs to be renewed in response to the requirements of the Act. A less strict Act would require a lower renewal rate, which could be interpreted as a lower quantity of CCA in this example. In this sense, the quantity itself can be seen as a function of the requirements of the regulation, such that $Q=Q(\boldsymbol{L})$, in which the vector $\mathbf{L}$ represents different characteristics of the regulation. In the present case, these characteristics refer to requirements stipulating the allowable length of power outages in urban and rural areas, as well as to the required uptake schedule. Each of these characteristics can be seen as one dimension of the vector $\mathbf{L}$, which determines the quantity of the public policy. 
The situation we have chosen to analyse is thus far from being a discrete-choice case, in which the only decision would be whether to implement the Act or not. This is true of nearly all public good decisions, such as deciding on the size of a dam (Hallegatte et al. 2012), the scale of proposed green infrastructure to prevent urban storm-water issues (Nurmi et al. 2016; Nordman et al. 2018) or the extent of early warning systems (Holland 2008).

We define over-adaptation as a situation in which a CCA policy instrument and its implementation increase the resilience of individuals and society but lead to a level of adaptation that is not economically efficient. This problem can be defined using a simple formula. Assuming diminishing marginal utility of benefits such that an increase in the quantity of the public good increases the benefits but at a diminishing rate, the formula can be written as follows:

$$
\sum_{i} M B_{i}(Q(\boldsymbol{L}))<M C
$$

If the marginal costs exceed the marginal benefits at some point of provision, less of the public good should be provided; that is, its quantity should be reduced to a level where the marginal benefit equals the marginal costs. However, even at this level of provision, the total benefit of the project can surpass the costs, resulting in a positive benefit-cost ratio or a positive net present value (NPV). This happens if the marginal benefits at lower levels of provision are high enough to compensate for the negative net benefits at higher levels. This situation is depicted in Fig. 1. By contrast, under-adaptation refers to a situation in which the adaptation policy or measure is implemented at a lower-than-optimal level. This is also depicted in Fig. 1.

$$
\begin{gathered}
Q^{1}: \operatorname{Max} B C R\left(Q^{1}\right)=\frac{B^{1}}{C^{1}}>0 ; N P V\left(Q^{1}\right)=B^{1}-C^{1}>0 ; M B>M C \rightarrow \text { underadaptation } \\
Q^{*}: B C R\left(Q^{*}\right)=\frac{B^{*}}{C^{*}}>0 ; \operatorname{Max} N P V\left(Q^{*}\right)=B^{*}-C^{*}>0 ; M B=M C \rightarrow \text { optimal adaptation } \\
Q^{2}: B C R\left(Q^{2}\right)=\frac{B^{2}}{C^{2}}>0 ; N P V\left(Q^{2}\right)=B^{2}-C^{2}>0 ; M B<M C \rightarrow \text { overadaptation }
\end{gathered}
$$

The optimal level of adaptation was derived from equation (2), which states that at the optimum the expected net present value (NPV) is maximised when marginal benefits and costs are at equal level, as in Figure 1 at level $Q^{*}$ and in equation (5).

Another commonly used indicator of the efficiency of a policy or measure is the benefitcost ratio (BCR). For example, Kelman and Shreve (2014) only report the BCRs of DRR and CCA measures, omitting studies that do not report the value. The BCR is a ratio of the net present value of benefits to costs, as shown in equations (4)-(6). As Figure 1 and equation (4) indicate, the ratio is typically highest at a low level of provision (e.g. at $Q<Q^{*}$ ). A low level of provision could correspond to the first systematic efforts to cope with climate change and to elementary disaster risk reduction programmes in developing countries. In Shreve and Kelman (2014), extremely high BCRs are reported for drought reduction measures in the Sudan and flood protection measures in India and the Philippines. Similar results are presented in Onuma et al. (2017a, 2017b), a study showing that experience of a disaster reduces the impact of future 


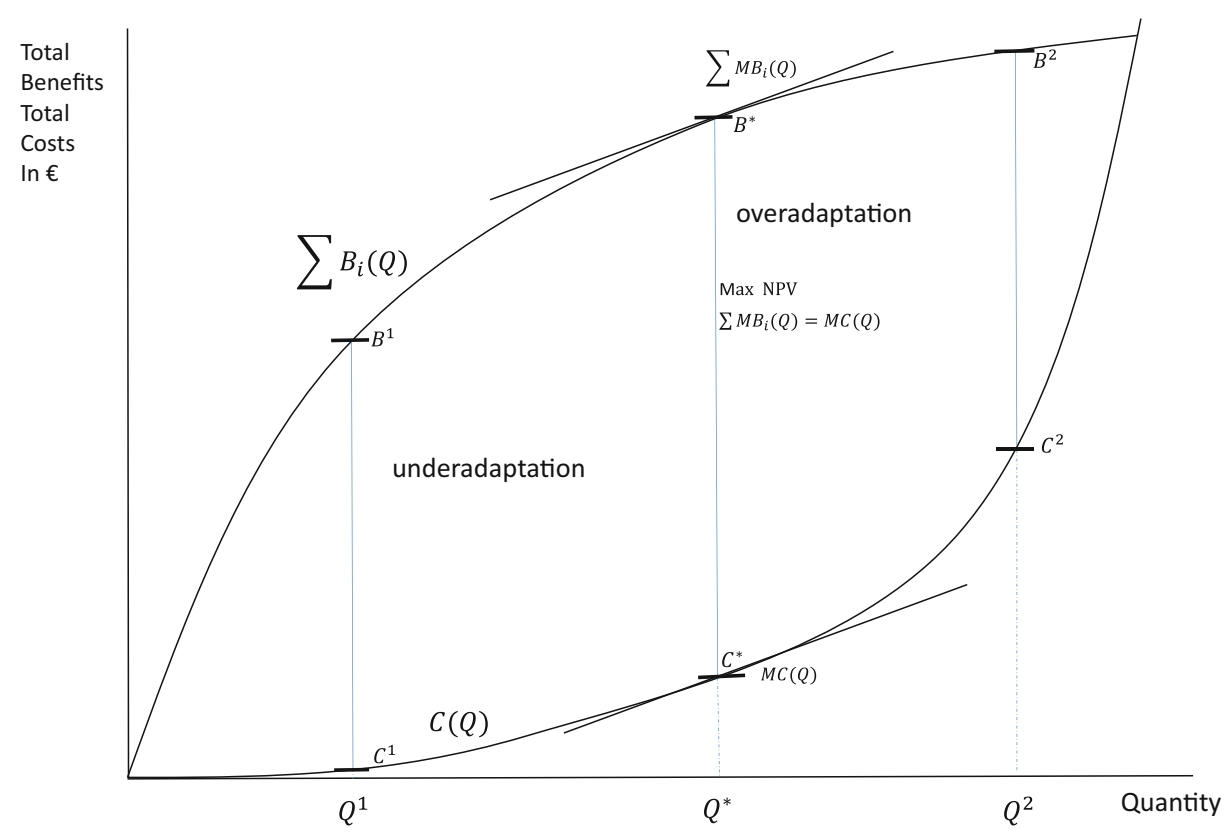

Fig. 1 Optimal adaptation, underadaptation and overadaptation

disasters more in in lower-income than in higher-income countries. However, the optimality of an adaptation policy or measure cannot be evaluated based on the BCR: in Figure 1 the BCR is maximised at $Q^{1}$, which corresponds to underadaptation.

We claim that the lack of evidence of overadaptation in the literature is partly due to the misuse of the BCR as a measure of the efficiency of adaptation instead of the NPV, a more appropriate indicator. The latter should be used where a sufficient number of different provision levels of $\mathrm{Q}$ are compared with each other.

CBA practitioners are well aware that NPV is the correct measure when ranking different policy options (e.g. Schwab and Lusztig 1969; Boardman et al. 2006; OECD 2018). If all different provision levels could be evaluated, the option with the highest NPV would represent with the optimal level of provision. In Figure 1 this corresponds to $Q^{*}$. By contrast, the highest BCR would be found at low provision levels and if used as a decision guideline would result in underprovision of the public good. Some caution should also be exercised when interpreting NPVs: if only one or several provision levels are evaluated, a positive NPV in itself only indicates a scale at which total benefits exceed costs. This can occur at levels of the public adaptation good, reflecting either underadaptation or overadaptation, as seen in Figure 1 and in equations (4)-(6). In such a, case, the interpretation of the NPV and BCR coincide, as pointed out by Shreve and Kelman (2014). Sometimes, even in the economics literature, a positive NPV is interpreted as indicating an efficient adaptation effort. (e.g. Mendelsohn 2012), but as explained above, this is not entirely correct. A thorough analysis should include several different provision levels, preferably spanning a wide range of provision. For example, Hallegatte et al. (2012) include three different levels of flood protection in their analysis: i) one medium-sized dam, ii) two smaller dams and iii) one small dam. Provided that the uncertainty in the analysis can be quantified, the option with the highest NPV should be chosen. In addition, when analysing different provision levels, a marginal analysis should be 
conducted at the recommended level of provision to determine whether the net benefits could be further increased by either reducing or increasing the provision level of the focal CCA policy or measure.

Finally, uncertainty is an inherent feature of CCA, so much so that the uncertainty related to climate change adaptation decisions has been termed "deep uncertainty". This can refer to any of three factors: 1) no clear consensus on which models should be used to assess the future, 2) an unknown probability distribution of key parameters and 3) an uncertain value of outcomes (Hallegatte et al. 2012). In such cases, it has been suggested that instead of calculating the expected NPV of investment decisions as a basis for decision-making, robust adaptation strategies should be adopted (Dessai and Hulme 2007; Hallegatte 2009; Hallegatte et al. 2012). These include (Hallegatte 2009) no-regret measures, which create benefits even in the absence of climate change; reversible measures, which are easily retrofitted if climate projections prove incorrect; safety margin measures, which reduce the vulnerability of a system at low or no cost; soft measures, which entail institutional or financial changes; reduced time horizon measures, which involve reducing the lifetime of an investment; and strategies that have synergies with mitigation. Based on the robust adaptation theory, a CBA analysing a CCA policy or measure should include at least a qualitative discussion of the robustness of the proposed actions.

\section{Cost Benefit Analysis for the 2013 Electricity Market Act}

\section{Methodological Issues}

We apply CBA to the reliability requirements of the 2013 Electricity Market Act. We assume cost minimisation for the maximum allowable blackout calculated for a given number of distribution companies in their market areas. As a cost, we include the infrastructure investment in underground cabling required to comply with the Act, calculated based on previous assessments (most notably Partanen et al. 2012). As a benefit, we include the avoided costs of blackouts estimated from blackout data and Willingness-to-Pay surveys and Value-of-LostLoad (VoLL) calculations for industrial users. The Finnish electricity network for low- and medium-voltage lines has been divided into regional monopolies. This being the case, all the costs will eventually be transferred to the customers as an increased rate for electricity distribution, and they will receive the benefits of the Act. The Act will benefit electricity market companies by decreasing their uncertainty relating to compensation costs from blackouts, costs that in the worst case might amount to $30 \%$ of their turnover. (Partanen et al. 2012; Saastamoinen and Kuosmanen 2016). To avoid double counting, we will not consider the decrease in compensation costs as a benefit.

We compare two different levels of provision, urban and rural, as differentiated in the law, and discuss the benefits and costs at the margin. Our results indicate that the Act results in a non-optimal level of provision of public adaptation, a case as yet unreported in the literature.

Smith et al. (2017) point to various factors hindering the use of CBA in many DRR-and CCA-related investments: imperfect valuation methods, sensitivity to assumptions regarding intergenerational preferences (e.g. discount rate), tendency to favour monetised (often tangible market) costs and benefits and inconsistent and often inadequate treatment of non-quantifiable (often intangible non-market) costs and benefits (Atkinson et al. 2008; Boardman et al. 2006; Bonzanigo and Kalra 2014; Florio 2014). In addition, CBA is distributionally insensitive 
(Adler 2013, in DRR CBA see Hallegatte et al. 2016) and often fails to analyse the distortionary effects of raising public funds, reflected primarily as impacts on the labour supply. (Boadway 2006; Bos et al. 2018).

Other methods, partly to overcome the obstacles related to the use of CBA, have been used and developed for assessing optimal investment levels of DRR and CCA measures (Smith et al. 2017; Watkiss et al. 2014). Real-option analysis is used in situations where it may be beneficial to wait before the cost-efficient investments are made, one instance being if the investment would benefit from more accurate information. Portfolio analysis is a tool to determine the efficient frontier of investment options, a point where the NPV of the combination of different options cannot be increased without increasing uncertainty at the same time. Portfolio analysis draws on modern portfolio theory, which is based on the idea of maximising profit and hedging risk by spreading the investment optimally over various assets. Portfolio theory can be used for CCA when a number of measures exist to reduce the risk of climate change and there is uncertainty about the benefits of individual measures. Robust decision making is a decision support method used under deep uncertainty, the purpose being to find CCA measures which will function well under various future scenarios (Lempert and Groves 2010; Lempert et al. 2013; Lempert 2014; Watkiss et al. 2014).

In our case, the reported limitations of CBA are not a major concern. First, the investment period of the infrastructure resulting from the renewed policy is estimated at between 50 and 70 years (Partanen 2015). This timeframe involves intergenerational issues over two or three generations; however, the cost of the capital investment will be paid by the customers and, contrary to what Weitzman (2001) suggests, time-declining interest rates should not be applied. Secondly, our case does not involve any major intangible ecosystem or health costs or benefits, but we have taken into account the value of bare forest land that is freed up as the electricity grid is moved from forest to roadsides. All in all, costs and benefits are relatively easy to estimate, as will be shown in the analysis in a later section.

Thirdly, distributional effects are taken into account in our CBA in two ways. In the first, the average willingness to pay (WTP) is applied for all individuals in the affected population rather than using a higher value for wealthier persons. This is the approach recommended by the European Environmental Agency in health economic studies (EEA 2009) and its theoretical aspects are discussed in Adler (2013). However, in our discussion, we take into account what this implies for the results between different regions. In the second, the spatial distribution of benefits and costs has been taken into account in the policy implications, discussed in section 5 .

Fourthly, distortionary effects have been left out of the analysis, as there is no adequate research regarding the labour supply effects of changing electricity prices. Most importantly, no alternative methods to CBA, suggested in Watkiss et al. (2014) and Smith et al. (2017), are needed in our analysis, as the Act is already in force and its implementation is under way. There is no opportunity to wait (a requirement for real-option analysis) and no alternative CCA measures can be used by the companies to meet the requirements of the Act (a requirement of portfolio analysis).

Fifthly, uncertainty related to parameter values is quantifiable and the resulting distribution of net benefits can be simulated with the Monte Carlo method. Monte Carlo simulation is a widely used method for analysing the impacts of uncertainty in the parameter values on the results of a CBA. If this uncertainty could be represented with contingent outcomes, one could simply illustrate the results of CBA using different scenarios. However, in the present case we have many uncertain parameter values, which precludes examining all the combinations of 
values. Our approach is to specify a distribution for each parameter value, take a set of random draws from each distribution, and repeat the trial a number of times. We follow suggestions of Boardman et al. (2006) when specifying the distributions. The resulting histogram can then be used to arrive at statistics about the outcome, such as the expected values and range of NPV and the significance of the results. (Boardman et al. 2006).

Finally, we should point out that our CBA considers implementation costs and directly related avoided costs only. A structural and substantial improvement of the electricity distribution network also has induced economic effects. For example, it may help to keep some residents and economic activity in the service area. Furthermore, some of the avoided costs represent actual expenditures rather than inconvenience costs, and these funds can be reallocated for consumption, creating more welfare. Then again, if prices rise more than consumers are willing to pay in a given area, this will create negative effects in the form of reduced purchasing power and areas becoming less attractive places to live. We disregard these spillover effects in the secondary markets in our CBA (Boardman et al. 2006) but discuss them in section 5, as they may be relevant information for cross-cutting policy goals.

\section{Analysis}

\section{Estimation of Benefits for Household Consumers}

Various methods are used to monetise the increase in the utility from an improvement in the quality or quantity of a good for individuals in society. Direct methods include contingent valuation, indirect ones travel cost or hedonic pricing. The disutility of a blackout for consumers is usually valuated using contingent valuation surveys, which elicit the willingness-to-pay (WTP) to avoid a blackout or willingness-to-accept (WTA) compensation for one.

The most recent such survey in Finland was carried out in 2014 (Matschoss 2014). Rather than the cost per unit of time, the survey asked respondents about their cost per value of lost load (VoLL). In our view, lost load is a harder concept for household consumers to understand than hours without electricity, but in the international literature VoLL is the standard method for reporting the cost of blackouts. However, surveys designed around VoLL often use questions related to inconvenience per time unit (London Economics 2013) and this can be directly converted to cost per time unit. As the average consumer in Finland uses approximately one kilowatt hour of electricity per hour, the VoLL per kilowatt hour is essentially the same as the cost of one hour without electricity.

Converted into hours of blackout, the average VoLL figures in Matschoss (2014) were WTP $1.5 € / \mathrm{h}$ and WTA $15 € / \mathrm{h}$. These were assumed to be linear over the duration of the blackout. The high disparity between WTP and WTA suggests behavioural anomalies; the income elasticity of WTP in the study was unrealistically high at 18 . The tenfold difference between the WTP and WTA implies that a consumer would not accept 14 euros in compensation for a one-hour blackout that he or she experienced, yet would not be willing to pay two euros to avoid the same blackout. Given such behavioural anomalies (e.g. Kahneman et al. 1991), these values are not directly applicable in a CBA. The responses to the WTP surveys also suggest that consumers do not necessarily support the lexicographic preferences adopted in national-level decision making (see section 4.4). Interestingly, the high divergence between WTP and WTA in the surveys suggests that an ownership effect obtains among consumers with regard to their right to undisrupted electricity consumption. (London Economics 2013). 
London Economics (2013) gathered international estimates for the costs of blackouts to households, and estimated VoLL figures in the UK. The range of WTP estimates in the literature is very wide. The smallest WTP for a one-hour blackout was $0.4 € / \mathrm{h}$ (Carlsson and Martinsson 2008). Accent et al. (2008) obtained a value close to $30 € / \mathrm{h}$. The WTP values in London Economics (2013), only about $1 € / \mathrm{h}$. are significantly lower than those in Finland. The WTA values reported, which ranged from 4 to $8 € / \mathrm{h}$ under different conditions, are closer to the Finnish estimates.

We apply two different methods to estimate the level of benefits that domestic consumers and industry obtain from the Act. For domestic users, the benefits are evaluated based on the duration of the avoided blackouts. The monetary benefits are estimated by combining the two Finnish contingent valuation surveys (Silvast 2005; Matschoss 2014) and values reported in the international literature (London Economics 2013). We drop the two lowest and two highest outliers in determining the range of WTP values; this yields a lower bound of $1.5 € / \mathrm{h}$ (Matschoss 2014) and an upper bound of $15 € / \mathrm{h}$ (Accent 2004), all converted into €2015.

The discrete time periods and amounts of lost energy consumption used in the literature have been scaled into a continuous model using the results of Silvast et al. (2005), who drew on a range of blackout durations to create a model very close to a continuous model. The study also provides a detailed description of the Finnish context. According to Silvast et al. (2005), the cost of the first second of a blackout for a household consumer is, on average, 1.7 euros in winter and 1.8 in summer; for a 36-h blackout the values are 368.7 euros and 366.5 euros, respectively. As the costs of blackouts between these two extremes were almost linearly distributed, we fitted a simple linear model (Table 1):

\section{Estimation of Benefits for Industrial Users}

We estimate the benefits for industrial users using the production function approach. VoLL is the appropriate measure as it allows scaling for the volume of production, reflecting the fact that the cost of a blackout of a particular duration is not the same for industrial users of different sizes. Table 2 below presents estimates of the loss of value-added production for different industries based on national statistics and recently updated by the Finnish Energy Authority (2015) using values reported in Mäkinen et al. (2009). In the table, VoLL $€ / \mathrm{kW}$ is the value of production lost due to a disruption (of any duration) in the supply of electricity and $€ / \mathrm{kWh}$ the value of production lost based on the entire duration of the blackout.

Statistics Finland (2014a) gathers statistics about the use of energy in different sectors. Within the sectors, companies are classified based on their turnover. For example, in the agricultural sector, $99 \%$ of the companies are small, having turnovers of less than $€ 100,000$. The average energy consumption for such a company is $20,000 \mathrm{kWh}$ per year, or $2.3 \mathrm{kWh} / \mathrm{h}$, and the average power is $25 \mathrm{~kW}$. The power and electricity use have also been calculated for the chemical, paper, metal and mining sectors. Only companies with a turnover less than $€ 400,000$ have been included in the above figures. Large facilities, whose turnover and consumption are greater, obtain their electricity directly from the high-voltage grid, which is a weather resilient.

Table 1 Output of the linear regression model

\begin{tabular}{llll}
\hline & Estimate & Std. Error & t-value \\
\hline Intercept & 9.8702 & 5.3269 & 1.853 \\
Length in hours & 10.1395 & 0.3138 & 32.314 \\
\hline
\end{tabular}


Table 2 VoLL for Finnish industrial users (Energy Authority 2015) and agriculture (Honkapuro 2006)

\begin{tabular}{lll}
\hline Sector & VoLL $€ / \mathrm{kW}$ & VoLL $€ / \mathrm{kWh}(€ 2015)$ \\
\hline Mining & 0.44 & 0.27 \\
Paper and wood & 2.60 & 0.23 \\
Chemical industry & 2.40 & 2.00 \\
Metal industry & 2.02 & 0.98 \\
Agriculture & 0.45 & 9.38 \\
\hline
\end{tabular}

\section{Estimation of Benefits from Reclaiming Bare Forest Land}

Underground cabling brings ecosystem benefits. For instance, one company in our data set estimates that in 2016,800 ha of what had been mainly forested land became made available when overhead lines were removed, and estimates that in the future the figure will be 1000 ha annually (Caruna 31.10.2017). This would correspond to approximately 2000 ha/year in our study area. To quantify these benefits, we use the figures from Tahvonen et al. (2013), who calculated the value of cleared forest land assuming optimal rotation periods. For an optimal land type in the study area, the value at a discount rate of $3 \%$ corresponds to $447 €$ per hectare; when the rate approaches $5 \%$, the value per hectare approaches zero. For a less optimal land type, the corresponding values are very low, $38 €$ and $-177 €$. We assume that in the case of negative values, the land will not be used for forestry; a minimum value of 0 and a maximum value of $€ 447$ per hectare is used in the Monte Carlo simulation. These values are already discounted for future profits. The benefits will be realised during the renewal phase of the network, a period spanning 15 years.

The length of power lines will increase due to their relocation from forest to roadsides. It has been estimated that in rural areas the increase in length will be 1.1 times for the lowvoltage network and 1.2 times for the medium-voltage network. (personal communication, Karvonen 2018). In the Monte-Carlo simulation, we specify a distribution with a range between 1.0 and 1.2 for the low-voltage network and between 1.1 and 1.3 for the mediumvoltage network.

\section{Estimation of Costs}

As noted above, compliance with the requirements of the Act requires a high level of investment in the case of both the low- and medium-voltage networks (Partanen et al. 2012). In particular, a significant proportion of the electricity network laid underground. To quantify the costs, we need to know the i) current extent of underground cabling, ii) required extent of underground cabling and iii) length of the network in rural and urban areas and iv) costs of underground as opposed to overhead lines. Partanen et al. (2012) present estimates of the required level of underground cabling in rural areas, where underground cabling of medium- and low-voltage networks are partial substitutes for each other; that is, by increasing the proportion of underground cabling in one network, the proportion can be decreased in the other, but at a diminishing rate.

Figure 2 illustrates the requirements for underground cabling rates in rural areas for the electricity distribution companies included in the analysis of Partanen et al. (2012). The set of companies is not the same as that in our analysis, but the same cabling rates are assumed to apply. Each coloured line represents the required rate for one company, and the dots describe the current extent of underground cabling. For instance, if the cabling rate for the low-voltage 


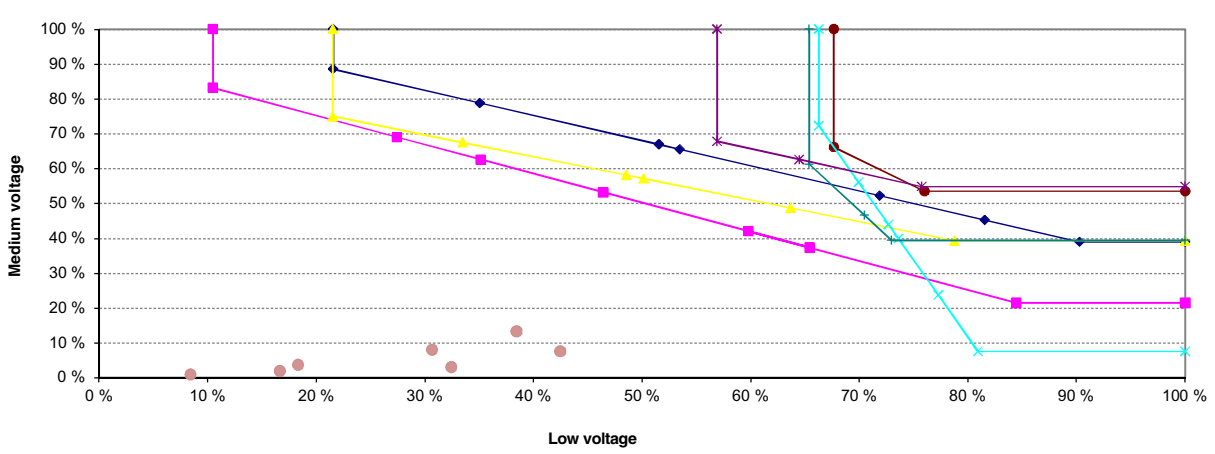

Fig. 2 Required level of underground cabling for seven electricity companies in rural areas (graph from Partanen et al. 2012)

network is $35-45 \%$, the rate for the medium voltage network must extend to $50-80 \%$; if the cabling rate of the low-voltage network is $70-90 \%$, the rate of the medium-voltage network needs to be between 20 and $60 \%$, depending on the company. These rates would make it possible to meet the $36-\mathrm{h}$ blackout limit. In urban areas, a $100 \%$ underground cabling rate is required for both the low- and medium-voltage networks to ensure compliance with the 6-h limit.

In our analysis, we assume that the companies choose the level of cabling that i) meets the requirements and ii) is the cheapest to produce. In other words, they comply with the Act but in a cost-efficient manner.

\section{Data}

To evaluate the increased reliability of the electricity grid, we need data on the current and expected blackouts in the analysed region. In Finland, electricity distribution companies are required to collect blackout statistics. The annual statistics are published by the Finnish Energy, an umbrella organisation of the energy companies in Finland, but the data are available only as an aggregate for all 80 companies operating in the country. To overcome this obstacle, we purchased raw data for eight companies from a private consultancy firm that analyses data for Finnish Energy (ENEASE 2016). This data set is also aggregated such that no individual company can be identified. However, we know the companies in the set and are able to analyse their network status. In addition to blackout data, we need the rate of underground cabling and customer information, which are provided by the Energy Authority (2015). Significantly, the operating areas of the companies form a single, representative region for which we can also analyse the weather and climatic conditions now and in the future.

The region encompasses Pirkanmaa region in south-western Finland as well as surrounding areas served by the electricity distribution companies operating in Pirkanmaa. The sample covers over $30 \%$ of the consumers in Finland, has both rural and urban areas in approximately the same proportion as the rest of Finland, and contains both large and small companies. Some of the companies are very small and local. Table 3 shows the distribution of consumers between different industries and household consumers among the eight companies.

For the costs, we need to know i) the present rate of underground cabling, ii) the length of both the low- and medium-voltage networks for all the operators, divided between urban and rural users, and iii) the costs of underground cabling for a unit of $(\mathrm{km})$ of network. 
Table 3 Users of the electricity grids in the study area

\begin{tabular}{llllll}
\hline $\begin{array}{l}\text { Division of different } \\
\text { user groups }\end{array}$ & Agriculture & Industry & $\begin{array}{l}\text { Services and } \\
\text { construction }\end{array}$ & Households & Total \\
\hline Share \% & 0.6 & 0.6 & 0.6 & 98.2 & 100 \\
Amount & 6600 & 6600 & 6600 & 080200 & 100,000 \\
\hline
\end{tabular}

The current level of cabling is public knowledge, provided in the annual reports of electricity companies. (Energy Authority 2015). These are shown for the eight companies in the area in Figure 3. The y-axis marks the current rate of medium-voltage underground cabling, and the $\mathrm{x}$-axis that of low-voltage underground cabling.

In the areas studied, the total length of the medium voltage network is $52,528 \mathrm{~km}$, and of the low-voltage network 99,708 km. (Energy Authority 2015).

Lastly, we need to know the average costs for both the low- and medium-voltage networks. Partanen et al. (2012) estimate for the medium-voltage network that underground cabling is two times more expensive than traditional overhead power lines, the costs being $61,700 € / \mathrm{km}$ compared to 28,800-32,200€/ km. Based on the data from the Energy Authority $(2011,2014$, 2016), a substantial decrease in the costs has occurred only in the case of the heaviest cables; the costs of other types and the average costs have remained almost constant. No substantial learning effects and resulting decrease in costs are expected, as thousands of kilometres of underground cables have already been installed.

For the low-voltage network, the difference in the costs between underground cabling and overhead lines in rural areas is smaller, approximately $3000 € / \mathrm{km}$, the figures being 21,000 $€ / \mathrm{km}$ and $18,000 € / \mathrm{km}$ respectively. Data collected from the electricity grid companies indicate that in urban areas the costs are again nearly twice as high for underground cabling, or 34,000 $€ / \mathrm{km}$ compared to $18,000 € / \mathrm{km}$ (Energy Authority 2016). The difference is explained by the more expensive digging costs in urban areas.

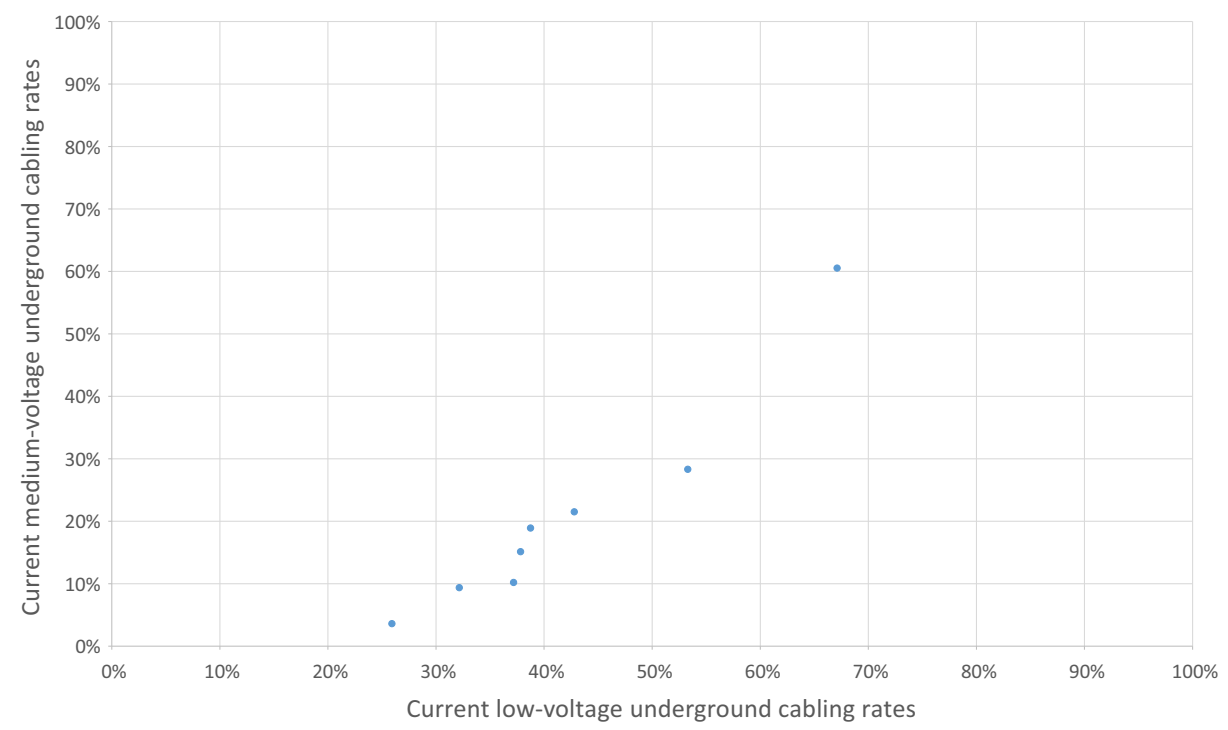

Fig. 3 The current state of the electricity network (Data from Energy Authority 2015) 
The blackout data cover the 10-year period from 2005 to 2014, which includes the years 2011 and 2013 that saw storms causing long blackouts in the study area. The return period for such storms cannot be estimated with current knowledge, as gust winds cause most of the major damage to trees - and most blackouts - but the measurement period for such winds has not been not long enough to produce return period estimates for a particular location.

Significantly, both the 2011 and 2013 storms occurred when the soil had yet to freeze. When the depth of soil frost extends less than $20 \mathrm{~cm}$, trees are not properly anchored to the ground and are thus very susceptible to uprooting (Gregow et al. 2011). As we are interested in the benefits of improving the reliability of the electricity grid in the future (time span 0 60 years), we have to consider the effects of climate change on weather phenomena, soil conditions and vulnerability of the sites affected.

First, we consider the current climatic conditions in the area of concern, that is, Pirkanmaa and surrounding areas, meaning southern, southwestern and central Finland. The current blackout risk can be calculated based on the 2005-2014 time series, which represents the degree of variability in the Finnish climate and the distribution of blackouts between years well (Figure 2). For the future climate, we first take a single-parameter approach. For extreme winds, the model estimates from the EU FP7 project Rain (Groenemeijer et al. 2016) show that extreme winds with an annual exceedance probability of 2\% in 1971-2000 will have a probability of $2.5 \%$ in 2021-2050 over southern and southwestern Finland. For 2021-2050, there is not much difference between different climate scenarios. From 2071 onwards, climate scenarios have a much greater impact on the annual high wind gust probabilities, but this falls largely out of the scope of our time frame. Annual blizzard probability is decreasing in southern Finland according to all climate scenarios. We can conclude that changes in gust wind or blizzards will not in themselves increase the risk of blackouts. An additional risk to the electricity grid to consider, however, is crown snow load, which is projected to increase in major parts of the country under all climate scenarios and time periods. However, the model results are not statistically significant at the $95 \%$ level except for the high-emission scenario RCP8.5 in 2071-2100 in southern Finland, where the results indicate a decreasing risk. (Groenemeijer et al. 2016).

Secondly, we assess the risk induced by climate change and its impact on soil frost (Gregow et al. 2011). These results suggest an increase in the risk of trees being uprooted, even if changes in the wind speeds do not occur. Gregow et al. (2011) indicates that the number of days when tree anchorage is poor will increase will from around 95 (1971-2000) to 185 days (2040-2065) in southern Finland; in other words, the risk of uprooting will nearly double. In central Finland, the corresponding numbers range from 90 to 125 days, implying a $40 \%$ increase in risk. However, we remain cautious in using these estimates, the increased risk has already been, to some extent, realised in our data due to the major storms in autumn and winter 2011 and 2013, which occurred with little or no soil frost.

Thus, we combine the increasing soil frost risk with the concurrent occurrence of strong winds and snow loads to describe the storm impact risk. As presented in Gregow et al. (2011 pp.48, Table 6), the risk of uprooting in the spruce-dominated areas in southern Finland will increase by $18 \%$ by 2046-2065 when using a SREX climate scenario A1B (Nakicenovic et al. 2000). This corresponds to RCP6.5 or RCP8.5 (Rogelj et al. 2012), depending on the period in question. In Jyväskylä, which reflects the conditions in central Finland, the projected increase is $13 \%$. While these estimates do not include changes in tree species or forest management by 2050, they do give an indication of the economic risk lying ahead in the spruce-dominated regions of southern and central Finland. 
In our analysis, we combine this information with the current risk of weather-induced blackouts. The low-end estimate of the future blackout estimate is based on the low-emission scenario, in which the conditions that led to blackouts in 2005-2014 do not change. In the medium- to high-end estimate, we use the risk level indicated by the high-emission scenarios, leading to a $13 \%$ to $18 \%$ increase in risk by 2045 . We assume a linear increase in the risk and extrapolate the increase for the remaining period 2045-2075. This leads to an asymmetric distribution for the annual increase in the risk ranging from 0 to $0.6 \%$.

\section{Results}

In a cost-benefit analysis, the timing of both the benefits and costs needs to be analysed and discounted to present value. This requires numerical parameter values, which we have obtained from various sources to analyse the costs and benefits as well as the uncertainties, in particular those affecting the benefits. Additional parameters affecting the uncertainty regarding future benefits are the rates of urban and rural population growth. Most underground cabling will be done in rural areas, but with Finland still undergoing rapid urbanisation this might affect the future benefits of the investment.

\section{Benefits}

The average annual number of weather-related blackouts was 34,360 in the study area, affecting on average 107 customers. As an aggregate, the consumers faced approximately 3,642,000 blackouts annually. The average length of a blackout was 3 h 20 min. Figure 4 shows the yearly number of blackouts.

We calculate the benefits by assuming that the requirements of the Act are achieved, thus assuming that the electricity network is upgraded according to the requirements of the Act. We divide the household users into urban and rural users (Statistics Finland 2016). In urban areas, we assume that no weather-related blackouts will occur as the underground cabling rate will be increased to $100 \%$. This results in annual benefits of 4.7-49 million $€$ (with mean 19.9 million $€$ ). In rural areas, we assume that the blackout frequency will be halved (as about $50 \%$ more of

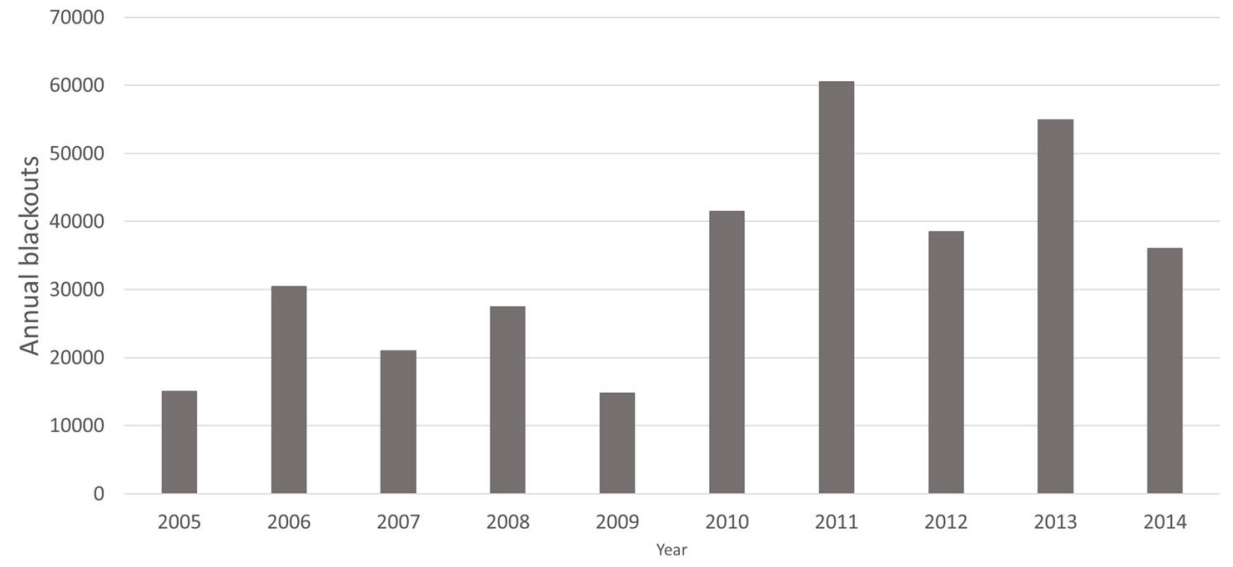

Fig. 4 Weather related blackouts in the study area in 2005-2014 
the network will be laid underground) and that no blackouts longer than $36 \mathrm{~h}$ will occur. This results in annual benefits of 6.8-70.9 million $€$. The wide range in both cases is due to the high disparity between the WTP figures reported in the literature. However, the triangular distribution fitted to the range of WTP figures has more probability mass for the values closer to the mean. The benefits are reported in 2015 euros.

For commercial users, we use the VoLL values shown in Table 2. Complementing these, we have collected data on a typical company in each sector and its power and annual electricity use (Statistics Finland 2017). As there are no data on the exact proportions of urban and rural industries, we use the more conservative assumption that the frequency of the blackouts will be halved. The projected benefits for each sector are shown in Table 4. Each sector included contains different subsectors, such as the food industry, wood industry and support services for mining, but as yet there is no VoLL available for sub-sectors separately.

Based on our analysis, the commercial benefits account for some $5 \%$ of the total benefits. In the international literature, the total damage costs to industry from blackouts is estimated at around 10\% (LaCommare and Joseph 2004). The difference stems from our case as we have taken into account only the small and medium sized industries. In Finland, large companies and industrial facilities are connected to the high voltage network and are outside the scope of this analysis.

\section{Costs}

In urban areas, the rate of underground cabling for both the low- and medium- voltage networks must be $100 \%$ to meet the requirements of the Act. The current rate for the lowvoltage network is around $70 \%$, and for the medium-voltage network 50-60\%. (Energy Authority 2015; Finnish Energy 2014). The investment cost for the former is 190-218 million $€$ and for the latter 160-182 million $€$. For both networks, we further assume that 50\% would have to be renewed in any case as part of scheduled maintenance, and 50\% would have to be laid underground prematurely. (Partanen et al. 2012).

The underground cabling rates for low- and medium-voltage power lines are partial substitutes in rural areas: increasing the rate in one network could lead to a decrease in the rate required in the other. Underground cabling of the low-voltage network is much cheaper, whereby the most cost-efficient approach is to increase the proportion of underground cabling until it no longer compensates the lower rate in the medium-voltage network. This rate (Partanen et al. 2012; Figure 1) is around $80 \%$. Thus, we assume that in rural areas the underground cabling rate of the low-voltage network will be $80 \%$. The required rate for the

Table 4 Benefits for commercial users

\begin{tabular}{llllll}
\hline & $\begin{array}{l}\text { Chemical } \\
\text { industry }\end{array}$ & $\begin{array}{l}\text { Wood } \\
\text { and Paper } \\
\text { industry }\end{array}$ & $\begin{array}{l}\text { Metal } \\
\text { industry }\end{array}$ & Mining & Agriculture \\
\hline Number of firms & 600 & 300 & 1500 & 150 & 5450 \\
Number of blackouts / year / firm & 3.3 & 3.3 & 3.3 & 3.3 & 3.3 \\
Length of blackouts / blackout (hours) & 3.37 & 3.37 & 3.37 & 3.37 & 3.37 \\
Annual damage / firm (2015€) & 2090 & 1770 & 1560 & 350 & 110 \\
Annual damage, sector (1000 2015€) & 1260 & 530 & 2300 & 50 & 600 \\
Annual benefit, sector (1000 2015€) & 630 & 270 & 1150 & 25 & 300 \\
Uncertainty range (1000 2015€) & $410-840$ & $180-360$ & $770-1560$ & $17-34$ & $200-400$ \\
\hline
\end{tabular}


medium-voltage network becomes 20-50\% (Partanen et al. 2012; Figure 1), leaving a high uncertainty range. An additional consideration is that the length of the electricity network is assumed to increase, as noted earlier (personal communication, Karvonen 2018). Ultimately, the total cost of meeting the requirements of the Act in rural areas will be 570-1460 million $€$. The wide range is due to the uncertainty in the required underground cabling rate, which depends on other measures to improve the network. A second source of uncertainty is the increase in the length of the low-voltage and medium-voltage networks when cables are removed from forested land and relocated to roadsides.

\section{Parameter Values}

Consumers of electricity obtain the benefits as soon as the investments have occurred and receive the benefits as long as the underground cables are used. For the distribution companies the investment costs are incurred immediately, but for consumers the cost is carried in keeping with the write-off schedule (typically a 30-year straight line-depreciation) and the capital cost of the investment. Consequently, the consumer benefits must exceed at least the weighted average cost of capital (WACC). In 2014, the WACC for electricity networks was 3.2-4.5\%. (Äijälä et al. 2014; Ernst and Young 2014) but the cost of external financing has since decreased by $0.5-1 \%$ (Bloomberg 2016). For the low end of the discount rate, we use $3 \%$. For the expected value, we use the average 12-month Euribor rate (since the euro area was established and Finland joined it in 2002) plus the current rate; for the high end, we use the highest Euribor rate plus the current cost of borrowed capital. It should be noted that economists (Weitzman 2001) recommend using a time-declining discount rate; in the present case, however, the benefits should be discounted by the cost of capital, as this will also be borne directly by the consumers. In estimating rural and urban population trends, we use projections calculated by the United Nations for Finland. WTP values were derived in section 3.2.1. The costs depend on the required underground cabling rates, as explained in section 3.2.3. Table 5 shows the ranges for the parameter values and their source.

\section{Monte Carlo Analysis and Net Present Value}

We ran a Monte-Carlo simulation with the above parameter values and distributions using the Palisade @Risk for Risk Analysis (2018) add-in to Microsoft Excel statistical software. The simulation was run $1,000,000$ times. The NPV of the benefits was estimated separately for improvements in the urban and rural networks. Figure 5 depicts the resulting distribution for urban areas. NPV is positive at the $95 \%$ significance level. The mean of the NPV distribution is 158 million euros. Of the variance in the NPV, the discount factor explains $86.1 \%$; costs, $1 \%$; WTP, $12.5 \%$; and the urban growth rate, $0.4 \%$.

Figure 6 shows the corresponding distribution for rural areas. The mean NPV is -374 million euros. There is a $96.2 \%$ probability that the NPV is negative in rural areas. In a noteworthy difference compared to urban areas, in rural areas the uncertainty in the costs of improving the network has a much larger effect on the variance of the NPV. This uncertainty explains $73.8 \%$ of the variance, while the discount factor explains only $21.6 \%$. Other factors explaining the variance include the uncertainty in the true value of WTP $(4.3 \%)$ and the decrease in the rural population $(0.3 \%)$.

To summarise, the expected NPV in urban areas is 158 million $€$, and in rural areas -374 million $€$. The expected benefits for industrial and agricultural users are 110 million $€$. To 


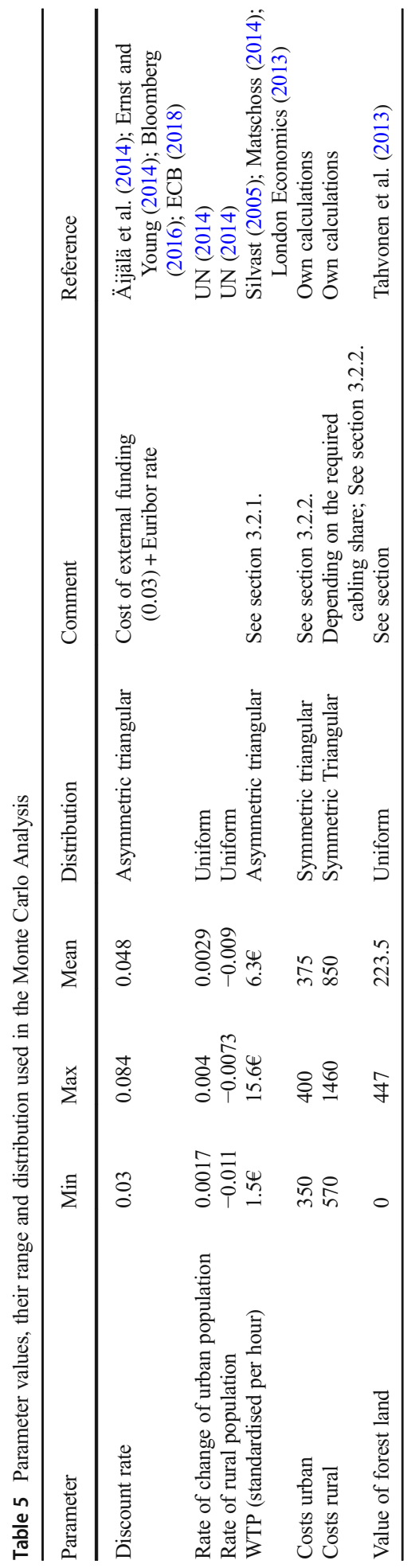




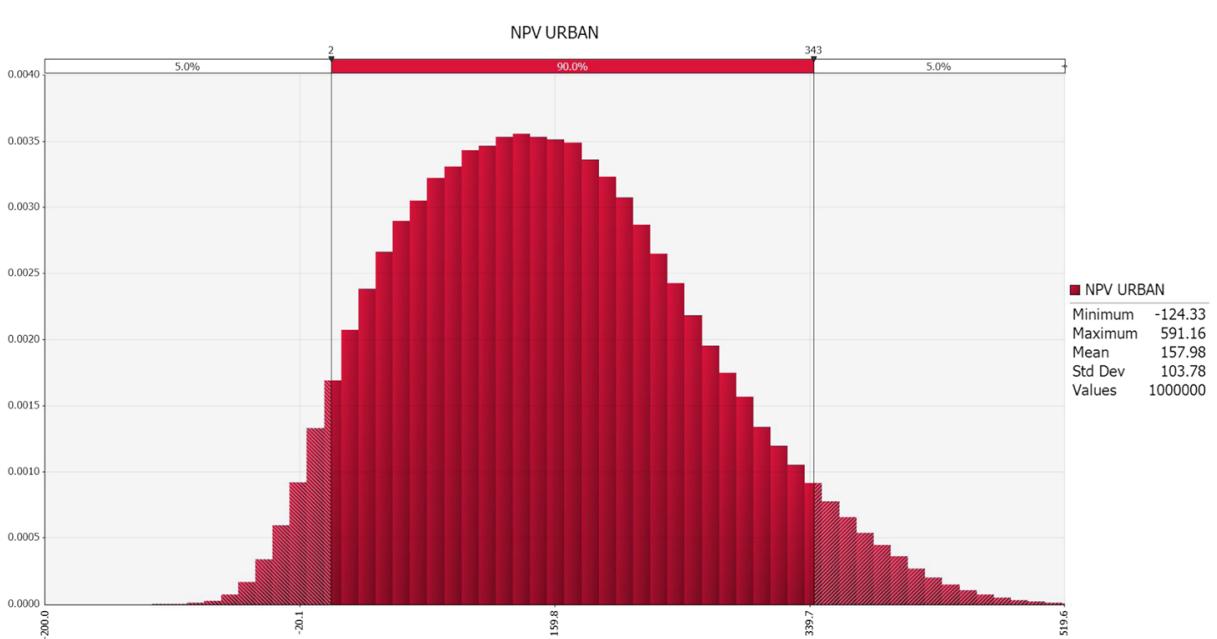

Fig. 5 The distribution of NPV for the urban areas

avoid double-counting, as the costs are already taken into account in the urban and rural analysis, the 110 million euros are added to the aggregate NPV, resulting in total expected NPV of -106 million euros.

The division of NPV between urban and rural areas only refers to the spatial component of the benefits and costs, not to the relative proportion of the investment costs ultimately borne by urban and rural consumers. In fact, if the electricity price increase is spatially uniform, urban customers ( $85 \%$ of the population) will bear most of the total cost (85\% assuming uniform electricity use and prices), while the majority of the benefits will go to the rural areas (expectation $40 \%$ vs. $60 \%$ ). However, if an electricity company operates only in a rural area, rural customers will pay all the costs, most likely resulting in greater rate increases than the customers are willing to pay. Clearly, at the margin, in rural areas the costs are higher than the benefits.

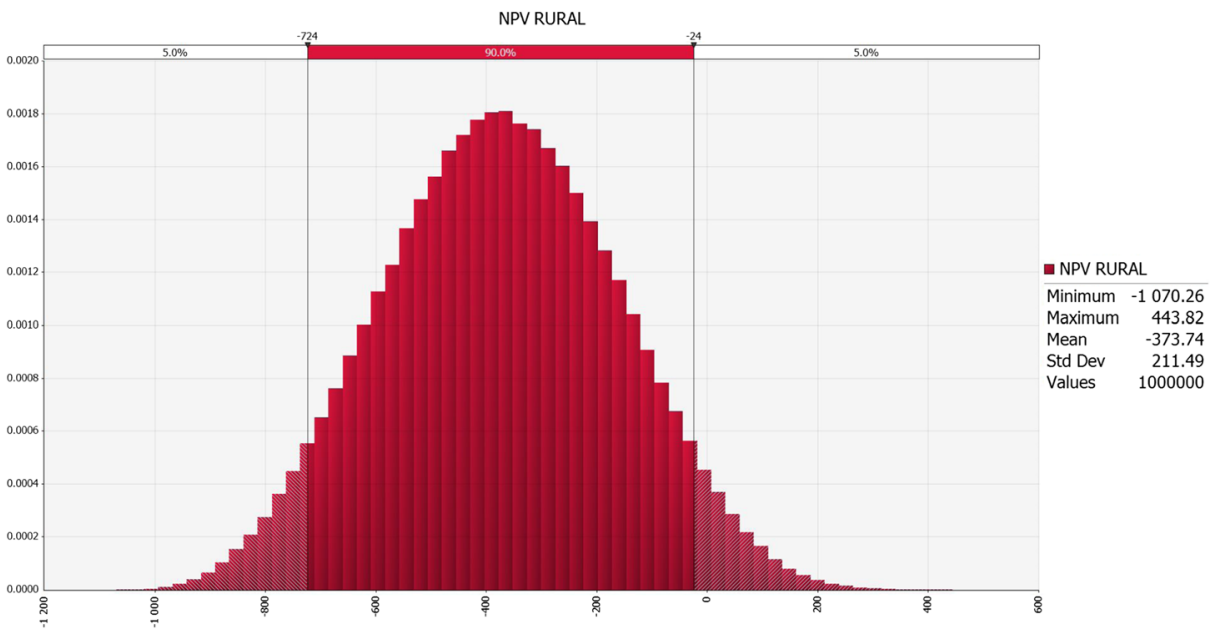

Fig. 6 The distribution of NPV for urban areas 
To further analyse the spatial distribution of the benefits and costs, we can divide electricity grid companies into three different categories, examples of which exist can be found in our data: 1) those operating only in rural areas, 2) those operating in both rural and urban areas and 3 ) those operating only in urban areas. The distribution of benefits and costs differs between these types. All three company types can be found at national level: of the 80 electricity distribution companies in Finland, the 15 largest supply electricity to $70 \%$ of the population. Two of the three largest suppliers have rural as well as urban customers. There are also companies that operate only at the scale of a rural municipality. (Finnish Energy 2017).

For companies in category 1 , costs are expected to be higher than benefits for the customers. In the case of those in category 2, customers in rural areas extract benefits from the urban customers and may become beneficiaries depending on the distribution of rural and urban customers. With companies in category 3, the NPV is positive at the $95 \%$ significance level, and the customers benefit from the requirements of the Act.

In section 2, we introduced the concept of robust adaptation, described in terms of five criteria (Hallegatte et al. 2009). Of these, the Act only fulfils the criterion of no-regret measures, as it clearly creates benefits even in the absence of climate change. However, the Act is not easily retro-fitted; it does not increase safety margins at a low cost; it cannot be classified as a soft measure inasmuch as it results in major investment costs; and the time horizon of the measure is long. Finally, synergies with climate change mitigation efforts are unknown.

\section{Public Reaction}

The requirements in the 2013 Electricity Market Act led to major price increases in electricity transmission and an ensuing public outcry over the situation. This following account of these events is based on two sources: the official public releases of one of the distribution companies most seriously affected by the public reaction, and the press releases of the office of the Finnish Consumer Ombudsman. No media reports have been used. The situation can be understood from the press release of 4 February 2016 by the company most heavily affected by the public reaction: "Caruna regrets the distress caused to its customers after having to come to a solution on price increases, due to the large-scale requirement for improvement. The company has advised its customers regarding the network improvement measures required by the Electricity Market Act (Electricity Market Act 588/2013), as well as the price increases connected with them. The price increases have resulted in a large number of objections from citizens as well as in considerable media attention" (Caruna 4.2.2016). The situation began in early 2016, when major price increases were announced by the company, the largest distribution company in Finland. On 3 February 2016, the Consumer Ombudsman released a statement saying that it considered the price hikes excessive from consumers' point of view (KKV 3.2.2016). The Ombudsman further stated that the price increases were unreasonable because electricity is considered a necessity good, and with the company having a regional monopoly, consumers cannot change their supplier. Negotiations with the company started. The outcome, reached towards the end of 2016, is summed up in the following statement: "Caruna will reduce its fixed basic prices for electricity transmission by 25 per cent for all customers and both of its network companies for the next 12 months. This compensation will also balance the price increase in 2017. Furthermore, Caruna has given a commitment that it will not implement new price increases in 2017." The Competition and Consumer Authority even considered bringing a class action suit against Caruna (KKV 18.2.2016). This procedure has never been used in 
Finland despite an Act providing for it being on the books since 2007 (Class Action Act 13.4.2007/444).

On 25 August 2017, the 2013 Electricity Market Act was amended to incorporate regulation against price increases by transmission companies. In principle, a cap of $15 \%$ has been imposed on increases in transmission and distribution prices over a one-year period. (Amendment to the Elecricity Market Act 590/2017).

Notwithstanding, in 2018 Caruna and several other companies implemented another series of price increases, prompting the government to initiate an official investigation into the reasons for the price hikes (TEM 28.5.2018).

\section{Discussion}

The impacts of the 2013 Electricity Market Act were evaluated from many different angles (Partanen et al. 2006; Partanen et al. 2012; Government Proposal HE 20/2013) before the Act was passed and enacted, but no CBA such as that presented here was conducted. Before the Act came into force, Partanen et al. $(2006,2012)$ pointed out that a previously suggested 24-h limit for rural blackouts would be economically inefficient and a 36-h limit would be economically more viable. Our analysis indicates that the 36 -h limit for the rural network is still too restrictive in some cases, as the benefits for the rural population are not high enough to justify the costs brought by the increased price of electricity distribution. We must note, however, that according to the ministry tasked with drafting the Act, the legislation had goals apart from reducing the impacts of extreme weather. Principal among these were the need to address the maintenance backlog and to ensure the security of supply throughout the country. The suboptimality we have described here is to be understood in strictly economic terms. Indeed, we acknowledge that a policy may be informed by other than economic objectives, such as national security, as noted above.

In Europe, we have seen a significant increase in damages to forests that have partly been caused by forest management practices that have favoured plantation of tree species (Norway spruce) that are easily uprooted (Gregow et al. 2017). By better forest management practices, the damages could have been less severe although not avoidable (Suvanto et al. 2016; Pukkala et al. 2016), whereby compliance with the Act cannot be guaranteed by these measures alone. However, the duration of blackouts in rural areas could be reduced with appropriate forest management, and the costs of doing so would be substantially smaller than the costs of laying underground cables. The economic efficiency of such measures - or less strict requirements for rural areas - should have been compared to underground cabling. The present analysis has evaluated only the 24- and the 36-h limits from an economic perspective. An additional consideration is that if the renewal of the network had a less strict deadline, overhead power lines could be used until the end of their technical lifecycle, and then be replaced by the underground cables. This would substantially decrease the total costs resulting from the requirements of the Act.

One limitation of our analysis is that the benefits may rise if WTP for avoiding of blackouts increases in the future, for instance due to an increasing dependence of households on electricity. Increasing income levels could also have an effect. In 2015, disposable income had not increased in the past decade (Statistics Finland 2014b); however, since 2015 there has been a slight increase in mean, but not median, disposable income. Moreover, as the income elasticity of WTP is not reported in the original studies, scaling up the WTP figures would be 
questionable. In addition, many electronic appliances now come with a battery. As battery technology improves, WTP values may well decrease. On balance, we feel that the current WTP range is wide enough to cover the uncertainty in consumers' WTP and thus have not considered any increase or decrease in the WTP.

As mentioned in Section 3.1, CBA should account for distortionary effects, primarily those related to labour supply resulting from changes in household preferences between labour and leisure. A distortionary effect means that due to income taxation the labour supply is not at its optimal level in the equilibrium (Johansson-Stenman 2005). If a proposed project increases the labour supply, its distortionary effects are positive, and if it decreases the supply, the effects are negative. There is little empirical evidence on the effect of changing energy prices on the labour supply; only the effects of demand have been studied rigorously (e.g. Asafu-Adjaye 2000; Papapetrou 2001). In our analysis, potential labour supply effects are more important, as the costs are mainly borne by household users; it is difficult to say anything certain about these or even about the direction of a possible change.

Distributional effects can be studied by comparing the benefits received by different income groups and assigning different social welfare weights to different groups, so that lower income groups are assigned a higher weight (e.g. Adler 2013), or by reporting the distributional issues qualitatively in the analysis (Nyborg 2014). In this analysis, it is possible to divide the individuals into urban and rural populations, as the benefits are distributed unevenly among the two groups. However, we cannot use individual benefitincome pairs as a basis for calculating distributional weights, and thus only report distributional effects qualitatively.

An analysis by the Bank of Finland (Mäki-Fränti 2016) has indicated that the income differences between regions in Finland are small. The five least urbanised regions have an average income $77 \%$ of those with the highest urbanisation rate (Mäki-Fränti 2016). In the analysis, we have used average VoLL figures for households for all different regions. Averages could be adjusted regionally to take into account the effect of income on VoLL. None of the primary literature studies report the income elasticity of VoLL, but Carlsson et al. (2011) report a positive income effect for the reported VoLL values. This would mean an even lower NPV for the rural case, but an improved NPV for the urban case. The differences in the production per capita in the rural and urban regions are much higher, but taxes and transfers decrease the income gap between urban and rural population. However, if distributional concerns are taken into account, both the benefits and the costs of the rural population should be assigned slightly higher weights than those of the urban population, making the rural case more negative.

Of greatest concern are those rural areas that have their own distribution company. In such cases, the rural population needs to pay a higher price for the increase in the electricity price as compared to its WTP. Even if less urbanised regions are not that poor on average, the poorest municipalities are located in the rural areas. Moreover, the share of low-income households is much higher in rural areas than in urban areas, around $4 \%$ compared to around 2\%. (Statistics Finland 2018). Electricity companies operating solely in rural areas may find it difficult to fully recoup their investment. They companies may consider not investing in underground cabling, but rather in improving their forest management practices around power lines. However, there is no guarantee that such measures will increase the reliability of the network to the standard required by the Act. The independence of such companies may be jeopardised, possibly resulting in mergers.

The literature (Onuma et al. 2016; Onuma et al. 2017a, 2017b) shows that CCA and DRR are often dynamic processes, as both individuals and societies learn from past disasters and 
increase their preparedness. In our case, the high impact storms in 2006, 2010 and 2011 clearly had an impact on public policy, and these experiences were part of the knowledge base informing the regulation. Our analysis shows that this dynamic process can also lead to an overreaction from the point of view of economic optimality.

\section{Conclusions and Implications}

Over-adaptation to the impacts of extreme weather and climate change has rarely been discussed in the literature. The literature is rich in examples where CCA and DRR measures are reported to be economically efficient, whereas counter-examples are few. We claim that this is due partly to reporting practices, and partly to imprecise definitions of efficient adaptation.

As a case study, we undertook a CBA of the 2013 Finnish Electricity Market Act, which imposes strict requirements on electricity distribution companies to prevent blackouts in their grid. Our results indicate that in urban areas the public policy and the required investment are economically efficient. However, in rural areas, the costs of the required investments exceed their economic benefits, indicating that the optimal requirements would have been somewhere between the old practices and the new. Depending on the operating area of a given electricity distribution company, the present requirements will result either in urban customers paying for the improved well-being of rural customers or rural customers having to bear the high cost of improving network reliability on their own. This cost is expected to be higher than the NPV for the improvement. Our results indicate that the present policy may be an overreaction to an existing problem: it seems that at some "quantity" (urban requirements), NPV is strictly positive, whereas at another level of service provision (rural requirements), NPV is negative.

Our case study indicates that over-adaptation is a relevant concept meriting consideration the CCA and DRR literature. Our case also shows that when assessing the success of public regulation and measures aiming at reducing the risk of extreme weather events and climate change, public opinion and potential and perceived negative effects on the public should be considered. The population affected by the impacts may not accept the implementation of otherwise effective DRR and CCA measures. This applies particularly when there is a potential mismatch between societal and individual preferences. Furthermore, the WTP of the people affected should be carefully evaluated prior to any policy change, as the WTP obtained in surveys may prove to be different from the WTP of the affected population. All in all, from the point of view of good governance, the significance of identifying over-adaptation is that it adds to our understanding of strong popular inclinations to avoid risks relating to the availability of an essential good, such as energy. Popular concerns may affect decision-making such that the resulting actions clash with the equally important objective of providing that good being at an affordable price.

Reducing the impacts of extreme weather events and adapting to climate change are challenging tasks given the many climatic, societal and political uncertainties. Despite these uncertainties, designing and implementing policy instruments and concrete measures is highly important due to the intensifying threat of climate change. Economic efficiency of the envisaged measures is one key criterion to be used in designing the instruments; however, the challenge for policy makers is to design instruments that are accepted by the public. 
System flexibility is essential in ensuring that the net benefits of a given project do not fall in the range of over-adaptation. This study has shown that CBAs evaluating potential CCA and DRR measures should better address suboptimalities.

\section{Appendix}

\begin{tabular}{l} 
Milestones and events \\
\hline A government report by an investigator" \\
Improving the reliability of electricity \\
network" \\
A government report" The compensation \\
costs for blackouts" \\
A working group named "“Preventing \\
disruptions in the electricity network \\
and improvement of the operational \\
goals" report: "Improving the reliability \\
of the supply of electricity"
\end{tabular}

A report by Technical University of Lappeenranta “

\section{Time and reference Notes}

2002 / KTM 18/2002 Early report including a discussion on the urban requirement of a maximum 6-h blackout.

2002 / KTM 11/2002 Early report including discussion on the compensation that customers are entitled in case of blackouts.

KTM 19.12.2006

The report included discussion on the blackouts statistics; historical development of blackouts; international comparison; discussion on the maximum allowed blackout periods; discussion and very crude estimates on the costs and benefits of increasing the underground cabling rates of lowand medium-voltage networks

Partanen et al. (2006) The report included a discussion as well as calculations of the benefits and costs of different maximum allowable blackout durations (6-10 h total blackout duration in one year under normal conditions, 24-48 h during major disturbances); It was concluded that the maximum of $6-10 \mathrm{~h}$ cumulative duration per customer is reasonable in normal conditions, but setting a strict time limit in case of major disturbances - such as storms - cannot be justified from an economic perspective; The report also mentions that for some (rural) electricity companies, there could be less strict deadlines.

TEM 16.3.2012

Included the final (acceptability) requirements of at maximum 6-h blackouts in urban areas, and either a 24- or a 36-h maximum duration in rural areas

Partanen et al. (2012) In this report is was concluded that the 24-h deadline for the maximum blackout periods in rural areas is too strict, and the $36 \mathrm{~h}$ deadline is more favourable from an economic point of view. Longer maximum blackout periods were not considered, as the proposal did not include them.

A proposal for the new Electricity Market Act. 
Open Access This article is distributed under the terms of the Creative Commons Attribution 4.0 International License (http://creativecommons.org/licenses/by/4.0/), which permits unrestricted use, distribution, and reproduction in any medium, provided you give appropriate credit to the original author(s) and the source, provide a link to the Creative Commons license, and indicate if changes were made.

Publisher's Note Springer Nature remains neutral with regard to jurisdictional claims in published maps and institutional affiliations.

\section{References}

Accent Marketing and Research. (2004). Consumer expectations of DNOs and WTP for improvements in service, London

Accent Marketing and Research. (2008). Expectations of DNOs and willingness to pay for improvements. A report to Ofgem

Adler M. (2013). Cost-benefit analysis and distributional weights: an overview. Working paper EE 13-04. Duke Law School

Adler MD (2016) Benefit-cost analysis and distributional weights: an overview. Rev Environ Econ Policy 10: 264-285

Äijälä M, Kemppinen O, Kauppila A. (2014). Kohtuullisen tuottoasteen määrittäminen sähkö- ja maakaasuverkkotoimintaan sitoutuneelle pääomalle. Loppuraportti Energiavirastolle https://www. energiavirasto.fi/documents/10179/0/EY_kohtuullinen_tuotto_WACC_loppuraportti.pdf/65533364-df154c0c-96ae-ad3d8a4268eb. Accessed 17 Jan 2019

Amendment to the Elecricity Market Act (Laki sähkömarkkinalain muuttamisesta) (590/2017) Annettu Helsingissä 25 päivänä elokuuta 2017. https:/www.finlex.fi/fi/laki/alkup/2017/20170590 (in Finnish). Accessed 17 Jan 2019

Asafu-Adjaye J (2000) The relationship between energy consumption, energy prices and economic growth: time series evidence from Asian developing countries. Energy Econ 22:615-625. https://doi.org/10.1016/S01409883(00)00050-5

Atkinson C, Mourate S, Szymanski S, Ozdemiroglu E (2008) Are we willing to pay enough to 'back the bid?: valuing the intangible impacts of London's bid to host the 2012 summer Olympic games. Urban Stud 45(2): 419-444

Barnett J, O’Neill S. (2010). Maladaptation

Bell CM, Urbach DR, Ray JG, Bayoumi A, Rosen AB, Greenberg D, Neumann PJ (2006) Bias in published cost effectiveness studies: systematic review. Bmj 332(7543):699-703

Bloomberg (2016). Bloomberg guide WACC. Available: http://businesslibrary.uflib.ufl.edu/c.php?g=114612 $\& p=746562$. Accessed 17 Jan 2019

Boadway R (2006) Principles of cost-benefit analysis. Public Policy Review 2(1):1-44

Boardman AE, Greenberg DH, Vining AR, Weimer DL (2006) Cost-benefit analysis: concepts and practice, vol 3. Prentice Hall, Upper Saddle River

Bonzanigo L., Kalra N. (2014). Making informed investment decisions in an uncertain world: a short demonstration. World Bank policy Research working paper 6765. https://doi.org/10.1596/1813-9450-6765

Bos F, van der Pol T., Romijn G. (2018). Should CBA's include a correction for the marginal excess burden of taxation?

Carlsson F, and Martinsson P. (2008). Does it matter when a power outage occurs? - A choice experiment study on the willingness to pay to avoid power outages. Energy Econ 30:1232-1245

Carlsson F, Martinsson P, Akay A (2011) The effect of power outages and cheap talk on willingness to pay to reduce outages. Energy Econ 33(5):790-798

Caruna (4.2.2016) https://www.caruna.fi/en/news/caruna-regrets-distress-caused-its-customers-and-respondsenergy-authority-report-electricity. Accessed 19 Mar 2018

Caruna (31.10.2017) https://www.caruna.fi/ajankohtaista/sahkoverkon-maakaapelointi-vapauttaa-vuositasollayli-1-000-hehtaaria-maata. Accessed 10 Nov 2017

Class Action Act (Ryhmäkannelaki) (13.4.2007/444) https://www.finlex.fi/fi/laki/ajantasa/2007/20070444 (in Finnish). Accessed 17 Jan 2019

COM (European Commission) (2013) Communication from the Commission to the European Parliament, the Council, the European Economic and Social Committee and the Committee of the Regions - An EU Strategy on adaptation to climate change. $\operatorname{COM}(2013) 216$ final 
Dessai S, Hulme M (2007) Assessing the robustness of adaptation decisions to climate change uncertainties: a case study on water resources management in the east of England. Glob Environ Chang 17(1):59-72

Easterbrook PJ, Gopalan R, Berlin JA, Matthews DR (1991) Publication bias in clinical research. Lancet 337(8746):867-872

ECB (European Central Bank) (2018) Statistical Data Warehouse. Euribor 1-year - Historical close, average of observations through period. http://sdw.ecb.europa.eu/quickview.do?SERIES_KEY=143.FM.M.U2.EUR. RT.MM.EURIBOR1YD .HSTA. Accessed 17 Jan 2019

EEA (2009) EC4MACS project websites. Conclusions at http://www.ec4macs. eu/downloads/reports/InterimAssessment/EC4MACS-InterimAssessment-chap5.pdf. Accessed 17 Jan 2019

Eisenack K (2014) The inefficiency of private adaptation to pollution in the presence of endogenous market structure. Environ Resour Econ 57:81-99. https://doi.org/10.1007/s10640-013-9667-6

Electricity Market Act (2013) 9.8.2013/588 / https://www.finlex.fi/fi/laki/ajantasa/2013/20130588 (In Finnish). Accessed 17 Jan 2019

ENEASE (2016) Private communication with the consultancy in charge of gathering data about the blackouts in Finland

Energy Authority (2011) Sähkönjakeluverkon verkkokomponentit ja yksikköhinnat vuodelle 2011. Statistics available: https://www.energiavirasto.fi/sahkonjakeluverkon-komponenttien-yksikkohinnat-vuodelle-2011 (In Finnish). Accessed 17 Jan 2019

Energy Authority (2014) Sähkönjakeluverkon verkkokomponentit ja yksikköhinnat vuodelle 2014. Statistics available: https://www.energiavirasto.fi/sahkonjakeluverkon-komponenttien-yksikkohinnat-20141. Accessed 17 Jan 2019

Energy Authority (2015) Sähköverkkotoiminnan teknisiä tunnuslukuja. Available: https://www.energiavirasto. fi/tunnusluvut2014 (In Finnish). Accessed 17 Jan 2019

Energy Authority (2016) Sähkönjakeluverkon verkkokomponentit ja yksikköhinnat 2016-2023. Statistics available: https://www.energiavirasto.fi/verkkokomponentit-ja-yksikkohinnat-2016-2023 (In Finnish). Accessed 17 Jan 2019

Ernst, Young (2014) A document prepared for Energy Authority to set the reasonable return on investment. https://www.energiavirasto.fi/documents/10179/0/EY_kohtuullinen_tuotto_WACC_loppuraportti. pdf/65533364-df15-4c0c-96ae-ad3d8a4268eb (In Finnish). Accessed 17 Jan 2019

Finnish Energy (Energiateollisuus) (2014) Sähkön keskeytystilasto 2014 (Electricity blackout statistics 2014 - in Finnish). Available: https://energia.fi/ajankohtaista_ja_materiaalipankki/tilastot/sahkotilastot/keskeytystilasto. Accessed 17 Jan 2019

Finnish Energy (Energiateollisuus) (2017) Sähköverkkoyhtiöt (Electricity grid companies) (in Finnish). Available: https://energia.fi/perustietoa_energia-alasta/energiaverkot/sahkoverkot/sahkoverkkoyhtiot. Accessed 11 Jun 2018

Florio M (2014) Applied welfare economics: cost-benefit analysis of projects and policies, 22. Routledge

Freeman M, Herriges J, Kling C (2014) The measurement of environmental and resource values. RFF Press, London

Government Proposal HE 20/2013 (in Finnish): Hallituksen esitys eduskunnalle sähkö- ja maakaasumarkkinoita koskevaksi lainsäädännöksi. HE 20/2013. http://plus.edilex.fi/tukes/fi/he/20130020. Accessed 17 Jan 2019

Gregow H, Peltola H, Laapas M, Saku S, Venäläinen A (2011) Combined occurrence of wind, snow loading and soil frost with implications for risks to forestry in Finland under the current and changing climatic conditions. Silva Fennica 45(1):35-54

Gregow H, Muzaffer EA and Laaksonen A (2017) Increasing large scale windstorm damage in Western, central and northern European forests, 1951-2010. Scientific Reports. (http://rdcu.be/q66j)

Groenemeijer P, Vajda A, Lehtonen I, Kämäräinen M, Venäläinen A, Gregow H, Becker N, Nissen K, Ulbrich U, Berlin F, Nápoles OM, Paprotny D (2016). Present and future probability of meteorological and hydrological hazards in Europe, Deliverable 2.5 of RAIN - Risk Analysis of Infrastructure Networks in Response to Extreme Weather. http://rain-project.eu/wp-content/uploads/2016/09/D2.5_REPORT_final.pdf. Accessed 17 Jan 2019

Hallegatte S (2009) Strategies to adapt to an uncertain climate change. Global Environmental Change 19:240247. https://doi.org/10.1016/j.gloenvcha.2008.12.003

Hallegatte S, Shah A, Lempert R, Brown C, Gill S (2012) Investment decision making under deep uncertaintyapplication to climate change. World Bank Policy Research Working Papers. https://doi.org/10.1596/18139450-6193

Hallegatte S, Vogt-Schilb A, Bangalore, M, Rozenberg J (2016). Unbreakable: building the resilience of the poor in the face of natural disasters. Climate change and development series. Washington, DC: World Bank. https://doi.org/10.1596/978-1-4648-1003-9. License: creative commons attribution CC BY 3.0 IGO

Hanemann WM (2000) Adaptation and its measurement: an editorial comment. Clim Chang 45:571-581 
Holland P (2008) An economic analysis of flood warning in Navua, Fiji. European Union Development Fund (EU EDF) 8 - SOPAC Project Report 122, Reducing Vulnerability of Pacific ACP States, Fiji Technical Report. SOPAC (Pacific Islands Applied Geosciences Commission), Suva, Fiji

Honkapuro S (2006). DEA-mallilla suoritettavan tehokkuusmittauksen kehittäminen. Tilaustutkimusraportti, Lappeenranta 2006

IPCC (2012). Managing the risks of extreme events and disasters to advance climate change adaptation: a special report of working groups I and II of the intergovernmental panel on climate change. Cambridge U

IPCC (2014) Annex II: Glossary [Agard, J., E.L.F. Schipper, J. Birkmann, M. Campos, C. Dubeux, Y. Nojiri, L. Olsson, B. Osman-Elasha, M. Pelling, M.J. Prather, M.G. Rivera-Ferre, O.C. Ruppel, A. Sallenger, K.R. Smith, A.L. St Clair, K.J. Mach, M.D. Mastrandrea, and T.E. Bilir (eds.)] Climate Change 2014: Impacts, adaptation, and vulnerability. Part B: Regional Aspects. Contribution of Working Group II to the Fifth Assessment Report of the Intergovernmental Panel on Climate Change

Johansson-Stenman O (2005) Distributional weights in cost-benefit analysis - should we forget about them? Land Econ 81:337-352

Kahneman D, Knetsch JL, Thaler RH (1991) The endowment effect, loss aversion, and status quo Bias. J Econ Perspect 5(1):193-206

Karvonen O (2018). Personal communication by e-mail and phone. [05.11.2018]. Osmo Karvonen, CEO, Nurmijärven Sähkö

KKV (Finnish Competition and Consumer Authority) (3.2.2016) https:/www.kkv.fi/en/current-issues/pressreleases/2016/3.2.2016-consumer-ombudsman-to-engage-caruna-in-negotiations-concerning-increases-toelectricity-transmission-prices/. Accessed 17 Jan 2019

KKV (Finnish Competition and Consumer Authority) (18.2.2016) https:/www.kkv.fi/en/current-issues/pressreleases/2016/18.2.2016-caruna-and-the-consumer-ombudsman-reach-a-negotiated-solution $\% 2 \mathrm{D} \% 2$ Dcaruna-will-phase-in-price-increases-over-a-longer-period-of-time/. Accessed 17 Jan 2019

Konrad KA, Thum M (2014) The role of economic policy in climate change adaptation. CESifo Economic Studies 60:32-61. https://doi.org/10.1093/cesifo/ift003

KTM (11/2002) Sähkökatkosten vakiokorvaukset, Kauppa- ja teollisuusministeriön työryhmä- ja toimikuntaraportteja 11/2002 (In Finnish)

KTM (18/2002) Sähkön toimitusvarmuuden parantaminen, Selvitysmiehen raportti, Kauppa- ja teollisuusministeriön tutkimuksia ja raportteja 18/2002. (In Finnish)

KTM (19.12.2006) Sähkönjakelun toimitusvarmuuden kehittäminen. Sähkön jakeluhäiriöiden ehkäisemistä ja jakelun toiminnallisia tavoitteita selvittäneen työryhmän raportti. (In Finnish)

LaCommare K, Joseph E (2004). Understanding the cost of power interruptions to U.S. Electricity Customers. pdf saatavilla: https://escholarship.org/uc/item/1fv4c2fv\#page-3. Accessed 17 Jan 2019

Lempert RJ (2014) Embedding (some) benefit-cost concepts into decision support processes with deep uncertainty. Journal of Benefit-Cost Analysis 5:487-514

Lempert, Groves (2010) Identifying and evaluating robust adaptive policy responses to climate change for water management agencies in the American west. Technological Forecasting \& Social Change 77:960-974

Lempert R, Kalra N, Peyraud S, Mao Z, Tan SB, Cira D, Lotsch A (2013). Ensuring robust flood risk management in Ho Chi Minh City. World Bank Policy Research Working Paper

London Economics (2013). The value of lost Load (Voll) for electricity in Great Britain. Final report for OFGEM and DECC

Mäki-Fränti P (2016). Alueelliset tuloerot Suomessa 2016 (in Finnish: regional income differences in Finland in 2016). https://www.eurojatalous.fi/fi/2016/artikkelit/alueelliset-tuloerot-suomessa-2016/. Accessed 17 Jan 2019

Mäkinen A, Bastman J, Järventausta P, Verho P, Repo S (2009). Sähkönsiirtoverkon häiriökeskeytysten aiheuttaman haitan arvioinnissa käytettävien parametrien päivittäminen, Tampereen Teknillinen YliopistoKuismin L. 2010. Ilmastonmuutoksen vaikutukset viemäröintiin ja jätevesien käsittelyyn. DI-työ. Aalto-yliopisto, Espoo. (In Finnish)

Matschoss K (2014). Laatukannustimen kehitys: raportti kuluttajakyselystä Helsinki: Kuluttajatutkimuskeskus. 68 Sivumäärä (Tutkimuksia ja selvityksiä / Kuluttajatutkimuskeskus; nro 9/2014) (In Finnish only)

Mendelsohn R (2012) The economics of adaptation to climate change in developing countries. Climate Change Economics 3:1-21

Møller AP, Jennions MD (2001) Testing and adjusting for publication bias. Trends Ecol Evol 16(10):580-586

Nakicenovic N et al. (2000). Special report on emissions scenarios (SRES): a special report of working group III of the intergovernmental panel on climate change. IPCC and Cambridge University Press. http://pure.iiasa. ac.at/id/eprint/6101/. Accessed 17 Jan 2019

Noble IR, Huq S, Anokhin YA, Carmin J, Goudou D, Lansigan FP, Osman-Elasha B, and Villamizar A (2014) Adaptation needs and options. In: Climate Change 2014: Impacts, Adaptation, and Vulnerability. Part A: Global and Sectoral Aspects. Contribution of Working Group II to the Fifth Assessment Report of the 
Intergovernmental Panel on Climate Change [Field, C.B., V.R. Barros, D.J. Dokken, K.J. Mach, M.D. Mastrandrea, T.E. Bilir, M. Chatterjee, K.L. Ebi, Y.O. Estrada, R.C. Genova, B. Girma, E.S. Kissel, A.N. Levy, S. MacCracken, P.R. Mastrandrea, and L.L. White (eds.)]. Cambridge University Press, Cambridge, United Kingdom and New York, NY, USA, pp. 833-868

Nordman E, Isely E, Isely P, Denning R (2018) Benefit-cost analysis of stormwater green infrastructure practices for Grand Rapids, Michigan, USA. J Clean Prod 200:501-510

Nurmi V, Ahtiainen H (2018) Distributional weights in environmental valuation and cost-benefit analysis: theory and practice. Ecol Econ 150:217-228

Nurmi V, Votsis A, Perrels A, Lehvävirta S (2016) Green roof cost-benefit analysis: special emphasis on scenic benefits. J Benefit-Cost Anal 7:488-522

Nyborg K (2014). Project evaluation with democratic decision-making: what does cost-benefit analysis really measure?, memorandum, Department of Economics, University of Oslo, no. 08/2014, dep. Of economics, Univ. of Oslo, Oslo. https://www.econstor.eu/bitstream/10419/102065/1/781242428.pdf. Accessed 17 Jan 2019

OECD (2018). Cost-benefit analysis and the environment: further developments and policy use. Organisation for economic co-operation and development (OECD), Paris

Onuma H, Shin KJ, Managi S (2017a) Reduction of future disaster damages by learning from disaster experiences. Nat Hazards 87(3):1435-1452

Onuma H, Shin LJ, Managi S (2017b) Household preparedness for natural disasters - impact of disaster experience and implication for future disaster risks in Japan. International Journal of Disaster Risk Reduction 21:148-158

Palisade @Risk for Risk Analysis (2018) http:/www.palisade.com/risk/default.asp. Accessed 17 Jan 2019

Papapetrou E (2001) Oil price shocks, stock market, economic activity and employment in Greece. Energy Econ 23:511-532. https://doi.org/10.1016/S0140-9883(01)00078-0

Partanen J (2015). Sähkönjakeluverkon komponenttien pitoaikojen rooli taloudellisessa valvonnassa. Nestra Oy. Found in: https://www.energiavirasto.fi/documents/10179/0/Caruna+Oy+ja+Caruna+Espoo+Oy+-+liite. pdf/ecf145dd-9a1e-4259-9a30-901bef520ea3. Accessed 17 Jan 2019

Partanen J, Lassila J, Kaipia T, Matikainen M, Järventausta P, Verho P, Mäkinen A, Kivikko K, Pylvänäinen J, Nurmi V-P (2006). Sähkönjakeluverkkoon soveltuvat toimitusvarmuuskriteerit ja niiden raja-arvot sekä sähkönjakelun toimitusvarmuudelle asetettavien toiminnallisten tavoitteiden kustannusvaikutukset. Tilaustutkimusraportti. Lappeenrannan teknillinen yliopisto \& Tampereen teknillinen yliopisto. (in Finnish)

Partanen J, Lassila J, Kaipia T, Haakana J (2012). Sähkönjakelun toimitusvarmuuden parantamiseen sekä sähkökatkojen vaikutusten lieventämiseen tähtäävien toimenpiteiden vaikutusten arviointi. Lappeenrannan teknillinen yliopisto 2012. (in Finnish)

Perrels A, Harjanne A, Nurmi V, Pilli-Sihvola K, Heyndricx Ch, Stahel A (2013) The contribution of weather and climate service innovations in adaptation to climate change and its assessment, deliverable 2.2, FP7 ToPDAd project, http://www.topdad.eu/publications. Accessed 17 Jan 2019

Pilli-Sihvola K, Väätäinen-Chimpuku S (2016). Defining climate change adaptation and disaster risk reduction policy Integration: Evidence and Recommendations from Zambia. International Journal of Disaster Risk Reduction. https://doi.org/10.1016/j.ijdrr.2016.07.010

Pilli-Sihvola K, Harjanne A, Haavisto R (2017) Adaptation by the least vulnerable: managing climate and disaster risks in Finland. International Journal of Disaster Risk Reduction. https://doi.org/10.1016/j. ijdrr.2017.12.004

Pukkala T, Laiho O, Lähde E (2016) Continuous cover management reduces wind damage. For Ecol Manag 372: 120-127. https://doi.org/10.1016/j.foreco.2016.04.014

Quentin Grafton R (2010) Adaptation to climate change in marine capture fisheries. Mar Policy 34(3):606-615. https://doi.org/10.1016/j.marpol.2009.11.011

Rivera C, Tehler H, Wamsler C (2015) Fragmentation in disaster risk management systems: A barrier for integrated planning. International Journal of Disaster Risk Reduction 14:445-456. https://doi.org/10.1016/j. ijdrr.2015.09.009

Rogelj J, Meinshausen M, Knutti R (2012) Global warming under old and new scenarios using IPCC climate sensitivity range estimates. Nat Clim Chang 2:248-253. https://doi.org/10.1038/nclimate1385

Saastamoinen A, Kuosmanen T (2016) Quality frontier of electricity distribution: supply security, best practices, and underground cabling in Finland. Energy Econ 53:281-292

Schwab B, Lusztig P (1969) A comparative analysis of the net present value and the benefit-cost ratio as measures of the economic desirability of investments. J Financ 24(3):507-516

Shreve CM, Kelman I (2014) Does mitigation save? Reviewing cost-benefit analyses of disaster risk reduction. International Journal of Disaster Risk Reduction 10:213-235. https://doi.org/10.1016/j.ijdrr.2014.08.004 
Silvast A, Heine P, Lehtonen M, Kivikko K, Mäkinen A, Järventausta P. (2005). Sähkönjakelun keskeytyksestä aiheutuva haitta. Tampereen teknillinen Yliopisto

Smith N, Brown C, McDonald G, Ayers M, Kipp R, Saunders W (2017) Challenges and opportunities for economic evaluation of disaster risk decisions. Economics of Disasters and Climate Change 1:111-120. https://doi.org/10.1007/s41885-017-0007-0

Statistics Finland (Tilastokeskus) (2014a) Tilastokeskus, Sähkön käyttö toimialoittain. https://www.stat. fi/til/tene/tau.html (in Finnish). Accessed 17 Jan 2019

Statistics Finland (Tilastokeskus) (2014b) Suomen virallinen tilasto (SVT): Tulonjakotilasto [verkkojulkaisu]. ISSN=1795-8121. pienituloisuus 2015, 2 Käytettävissä oleva rahatulo keskimäärin 37900 euroa . Helsinki: Tilastokeskus [viitattu: 11.6.2018]. (in Finnish) Saantitapa: http://www.stat.fi/til/tjt/2015/02/tjt_2015_02_201703-24_kat_002_fi.html. Accessed 17 Jan 2019

Statistics Finland (Tilastokeskus) (2016) Väestörakenne (Population structure). Available: http://www.stat. fi/til/vaerak/index.html (In Finnish). Accessed 17 Jan 2019

Statistics Finland (Tilastokeskus) (2017) Sähkön hinta kuluttajatyypeittäin, Energian hinnat. Tilasto saatavilla: http://www.stat.fi/til/yrti/ (In Finnish). Accessed 17 Jan 2019

Statistics Finland (Tilastokeskus) (2018) Suomen virallinen tilasto (SVT): Tulonjakotilasto [web article]. ISSN=1795-8121. Helsinki: Tilastokeskus [viitattu: 11.6.2018]. (in Finnish) Saantitapa: http://www.stat. fi/til/tjt/. Accessed 17 Jan 2019

Suvanto S, Henttonen HM, Nöjd P, Mäkinen H (2016) Forest susceptibility to storm damage is affected by similar factors regardless of storm type: comparison of thunder storms and autumn extra-tropical cyclones in Finland. For Ecol Manag 381:17-28. https://doi.org/10.1016/j.foreco.2016.09.005

Tahvonen O, Pihlainen S, Niinimäki S (2013) On the economics of optimal timber production in boreal scots pine stands. Can J For Res 43(8):719-730

TEM (Ministry of Economic Affairs and Employment of Finland) (16.3.2012) Työ- ja elinkeinoministeriön ehdotus toimenpiteistä sähkönjakelun varmuuden parantamiseksi sekä sähkökatkojen vaikutusten lievittämiseksi. (In Finnish)

TEM (Ministry of Economic Affairs and Employment of Finland) (28.5.2018) Professori Jarmo Partanen selvittämään sähkön jakeluverkkojen hinnankorotuksia ja niiden alueellista kohdentumista. http://tem. fi/artikkeli/-/asset_publisher/professori-jarmo-partanen-selvittamaan-sahkon-jakeluverkkojenhinnankorotuksia-ja-niiden-alueellista-kohdentumista. Accessed 17 Jan 2019

Tol RS (2005) Adaptation and mitigation: trade-offs in substance and methods. Environ Sci Pol 8:572-578

UN (United Nations), Department of Economic and Social Affairs, Population Division. (2014) World urbanization prospects: the 2014 revision, CD-ROM Edition

Watkiss P, Hunt A, Blyth W, Dyszynski J (2014) The use of new economic decision support tools for adaptation assessment: a review of methods and applications, towards guidance on applicability. Clim Chang 132:401416. https://doi.org/10.1007/s10584-014-1250-9

Weitzman ML (2001) Gamma discounting. Am Econ Rev 91(1):260-271 